Neža Zajc (Ljubljana)

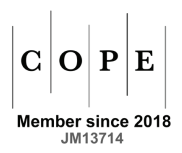

\title{
The Byzantine-Poetic Path of the Works of St. Maximus the Greek (Mikhail Trivolis, *Arta, CA. 1470 - St. Maximus The Greek, †Moscow, 1556)*
}

\section{Some biographical notes ${ }^{1}$}

$\mathrm{M}$ ikhail Trivolis was born around 1470 in the Greek Macedonian town of Arta, which at that time became administratively Orthodox ${ }^{2}$. He received his initial education from his relative (probably an uncle) Demetrius Trivolis, a bibliophile with well-established links to Greek and Italian scholars. The young Mikhail was invited to travel to Corfu and to northern Italy - possibly by Iannos Laskaris, who visited Trivolis in Arta while searching for valuable manuscripts for the Medici library. While on Corfu, Mikhail Trivolis became close with Greek scholars and philologists ${ }^{3}$ such as Marco Musuros and Demetrius Halkhondyle, learned men of the Moschos family ${ }^{4}$. Together, they travelled to Italy along the

\footnotetext{
* This article has been written under the research programme P6-0094 (A), financed by the National Government of Slovenia (ARRS).

${ }^{1}$ Our method follows two main principles. Firstly, we purposely limit ourselves to the author's (i.e. Maximus the Greek's) viewpoint of the concrete historical period. Secondly, we are dealing only with manuscripts from his lifetime; all conclusions and goals of the present investigation are reached on the basis of these texts. As a result, we are focusing on a handful of carefully selected manuscripts (from the $16^{\text {th }}$ century) that were deemed highly authoritative in the process of extensive analytic reading. In other words, we are not dealing with a chronologically quantitative list of Maximus the Greek's manuscripts - rather, with simultaneously listed manuscripts that may be said to have preserved his "fingerprints" (metaphorically speaking). This kind of method could be named "synchronic-diachronic", as opposed to plain "linear diachronic argumentation". Additionally, up-to-date information from biographical sources is indispensable; only such data may offer a sufficiently objective biographical frame. Consequently, the above-described method enables us to bring to light some significant details that may have been neglected or overlooked in past studies. Moreover, our research is firmly based on the precise comparative analysis of the personal Slavic idiom of Maximus the Greek, often misunderstood by previous scholars. For this reason, some observations in this paper might appear unexpected; nevertheless, we are convinced that they are fully justified.

${ }^{2}$ I. ŠEvČEnko, The Four Worlds and the Two Puzzles of Maxim the Greek, Psl 19, 2011, p. 294.

${ }^{3}$ Н.В. Синицына, Максим Грек, Москва 2008 [= ЖЗЛ. СБ, 1362], p. 18-19.

${ }^{4}$ E. Denissoff, Maxime le Grec et l'Occident, Paris-Louvain 1943, p. 140-143.
} 
Greek and Croatian islands. Mikhail first established himself in Florence, dedicated to the Holy Annunciation of Virgin Mary, which left a deep impression in his imagination for all his life (he remembered this city as the most beautiful and the most wonderful town in the Italian land that he had ever seen ${ }^{5}$ ). In the Florence apartment of Iannos Laskaris, who became Mikhail's supervisor in his translation and linguistic endeavours, he was introduced to the elite community of scribes, translators, and professional calligraphers, who were carefully carrying out the process of transmitting ancient manuscripts into a new, printed form. Already in $1492^{6}$, in Florence, Mikhail Trivolis established the first contacts with Aldo Manuzio; furthermore, he became acquainted with such Florentine humanists and intellectuals as Marsilio Ficino ${ }^{7}$, Cristophoro Landino ${ }^{8}$ or Angelo Poliziano9. While in Florence, Mikhail transcribed the Greek manuscript of the Geoponica for Iannos Laskaris, twice ${ }^{10}$. In this manuscript, Mikhail Trivolis left a signature, which not only provides certain chronological evidence, but also constitutes an important sign of self-identification. It shows that Trivolis was aware of the concept of non-anonymous work - a most bold and progressive thought from an early Renaissance perspective. Mikhail also copied Strabo's Geography, in which manuscript he first used his special forms of handwritten Greek words and letters (Gr. $k, m, n$ ), which he kept on using for the remainder of this life (cf. the resemblance of his Greek manuscripts - for example, in the Greek Psalter, which he copied in Russia) ${ }^{11}$. Mikhail concluded this manuscript with verses forming an ode to the ancient author. His copy of the manuscript of Joseph Flavius's Antiquities of the $J w^{12}{ }^{12}$ contains certain expressions indicating facts from his personal biography; for example, he later noted that he travelled to the south edge of Western Europe from the Alps and the Pyrenees to Gadeir ${ }^{13}$ (in the First Polemical Letter to Fiodor

\footnotetext{
${ }^{5}$ Paris, Bibliothèque Nationale (BN), Slav. 123, f. $461 \mathrm{r}$.

${ }^{6}$ D. Speranzi, Michele Trivoli e Giano Lascari. Appunti su copisti e manoscritti greci tra Corfù e Firenze, SSla 7, 2010, p. 275-276.

${ }^{7}$ The first Latin translator of Dionisus Areopaghyte.

${ }^{8}$ M. Garzaniti, Michele Trivolis/Massimo il Greco (1470 - circa-1555/1556). Una moderna adesione al vangelo nella tradizione ortodossa, CS 36, 2015, p. 343.

${ }^{9}$ E. Denissoff, Maxime..., p. 152.

${ }^{10}$ Paris, Bibliothèque nationale (BN), Gr. 1994, cf. E. Denissoff, Maxime..., p. 88. During the lifetime of Laskaris, this manuscript was handed over to the Italian poet, diplomat, and philologist Andrea Nauggerii (1483-1529), Б.Л. Фонкич, Новый автограф Максима Грека, [in:] IDEм, Греческие рукописи и документы в России в XIV - начале XVIII в., Москва 2003 [= РХВ.Б, 4], р. 77-79.

${ }^{11}$ Sankt Petersburg, Russian National Library, РНБ, Соф. 78.

${ }^{12}$ Vatican, Biblioteca Apostolica Vaticana: A Geography of Strabo (Reg.gr. 83); Joseph Flavius's Antiquities of the Jews (Barb.gr. 100).

${ }^{13}$ Lat. Gades, Gr. Gadeir (Cádiz, a town in Southern Spain). The same expression was used in the works of Sigismund Herberstein, cf. The Gratae Posteritati (Edition Stored in Ptuj, 1560), Ljubljana 2017, p. 45. The Russian scholar maintains that “Gadir" means Gibraltar, А.И. Иванов, Литературное наследие Максима Грека. Характеристики, атрибуиии, библиография, Ленинград 1969, р. 174.
} 
Karpov Against the Latins $\left.{ }^{14}\right)$. Mikhail Trivolis was also once in possession of his own copy of Dioscorides ${ }^{15}$ (printed in 1499 by Manuzio) - first owned by Trivolis at Corfu, then by Georgios Moschos, and subsequently by Mikhail's cousin, Antonio Eparque ${ }^{16}$. Clearly, he transcribed the oldest and most sought-after Greek books, all of them records of previously illuminated manuscripts. Besides, he was most probably included in the group of educated men who were engaged in the project of the planned Medici Library. Within a few years, Mikhail was already in touch with the newly established printing house of Aldo Manuzio in Venice; he became part of the editorial group responsible for newly printed Greek books. At that time, in Manuzio's printery, the programme of Nel'Accademia was being formed. There, he met other Greek colleagues, members of the second Greek diaspora - Iannos Grigoropulos, Aristobule Apostolios, Nikolas Sofianos ${ }^{17}$, Zacharias Kalliergis (Cretan calligrapher and founder of the Greek Press in Medici Rome), Nikolas Vlastos ${ }^{18}$, Pietro Bembo (Venetian historiographer and expert in the Slavic areas forming part of the Venetian Republic), and philologist Giovanni Crastone. His correspondence with Scipio Carteromach and Ioannos Grigoropulos from that period is quite well preserved ${ }^{19}$. Manuzio purposefully chose the original handwritten script of Mikhail Trivolis as the model ("Druckvorlage") for the first prints of the Idylles of Theocritus ${ }^{20}$. Like Marco Musuros (the first professor of Greek at the University of Padova and the first censor of Greek books in Venice in 1503, who created over 200 lines $)^{21}$ and Demetrios Moschos, Mikhail Trivolis started cultivating his own poetic creativity; this occurred already in Florence. The first verses of his own can be found in the marginalia of a manuscript that contained the works of Ermogen, Sirianus, and Sopatro ${ }^{22}$, which were in many respects part of the canon of Byzantine rhetoric and poetics, especially concerning the recognition of the rhythm and the metre ${ }^{23}$ (the rhythmical unit of prose and the rhythmical unit of verse). In the marginalia of this manuscript, Mikhail included a form of monokondylion containing the name of his father - Manuel ${ }^{24}$. Later, he also

\footnotetext{
${ }^{14}$ ПРеПОДОБНЫЙ МАКСИм ГРеК, Сочинения, vol. I, Москва 2008 (cetera: ПРеП. МАКСИм ГРЕК I), p. 177.

${ }^{15}$ E. Denissoff, Maxime..., p. 88.

${ }^{16}$ Ibidem, p. 143.

${ }^{17}$ I. ŠEvČenko, The Four..., p. 296.

${ }^{18}$ E. Denissoff, Maxime..., p. 88-89.

${ }^{19}$ ПреП. МАКСИМ ГРеК I, p. 101.

${ }^{20}$ Н.В. Синицына, Максим Грек..., p. 34; D. Speranzi, Michele..., p. 280, an. 94.

${ }^{21}$ I. ŠEvČEnKo, On the Greek Poetic Output of Maksim Grek, Bsl 58, 1997, p. 61.

${ }^{22}$ In June 1491, Iannos Laskaris visited Demetrios Trivolis with the aim of acquiring the manuscripts of Sopatro for the library of Lorenzo Magnifico Medici, E. Denissoff, Maxime..., p. 128.

${ }^{23}$ V. Valiavitcharska, Rhetoric and Rhythm in Byzantium. The Sound of Persuasion, CambridgeNew York 2013, p. 33.

${ }^{24}$ D. Speranzi, Michele..., p. 266, an. 23, p. 278, 280; E. Denissoff, Maxime..., p. 136.
} 
used the rhythmical principle of poetry (hexameter, pentameter - heroic metre, and iambic ${ }^{25}$ ) in his theological and polemical prose writings.

Mikhail Trivolis also visited Milan and Ferrara; twice, he stayed at the Mirandola castle ${ }^{26}$ for a longer period, teaching the Greek tongue to Gianfrancesco della Mirandola. At Mirandola, he firstly studied the corpus of Dionisius Areopaghyte. As we learn from Mikhail's letters from Mirandola sent to Ioannos Grigoropulos and to minor canon Nicolla Tarassci in Vercelli (March 29 ${ }^{\text {th }}, 1498$ ), he also received a letter of invitation from humanist Antonio Urceo Codro to work as a professor of Greek at the University of Bologna. Trivolis did not decide to accept this kind of post, however ${ }^{27}$. Under profound spiritual influence of the public theological preachings of Girolamo Savonarola, in 1502 he joined the Dominican Monastery of San Marco in Florence. Still, he was not ordained, staying there as a novice for about two years (1501-1503). He left the Monastery of San Marco in 1504 due to reasons of a strictly personal nature ${ }^{28}$. He was only able to find spiritual peace in working with manuscripts and first-printed books in Manuzio's printery in Venice. In that city, Mikhail was involved in the preparations for the printing of Greek Orthodox liturgical books (Byzantine books for the Holy Liturgy) ${ }^{29}$. Aldo Manuzio, to whom Maximus later referred as the "wise Romanian" ${ }^{30}$, devised a special plan for the printing of Greek liturgical books, which, however, was never implemented. In fact, two earlier attempts to print liturgical books for Orthodox Christians had also failed: the first was due to the Cretan Georgios Alexandrou, who printed the Psalterion in Venice in 1486, while the other was by Aldo Manuzio himself ${ }^{31}$. In 1498-1500, the first Greek Orthodox community was established in Venice, known as the School of St. Nicholas (later joined by Marco Musuros) $)^{32}$.

In 1505, Mikhail Trivolis left Italy. His theological and monastic worldview took final shape at Mount Athos, in the Holy Monastery of Vatopaidi, dedicated to the Holy Annunciation. There, he was ordained as a monk in $1506^{33}$, receiving the

${ }^{25}$ E. Denissoff, Maxime..., p. 142.

${ }^{26}$ Also preserved is a letter from 1500 that Mousouros wrote to Trivolis, residing in Mirandola at the time (Milan, Biblioteca Ambrosiana, Id. 2002).

${ }^{27}$ E. Denissoff, Maxime..., p. 89; ПреП. МАКСим Грек I, p. 87-89.

${ }^{28}$ ПреП. МАкСим Грек I, p. 98-99; Н.В. Синицына, Раннее творчество преподобного Максима Грека, [in:] ПРеПоДОБНЫЙ МАКСИм ГРек, Сочинения, vol. I..., p. 18.

${ }^{29}$ Psaltery, Venice 1485; Horologion, Venice 1509; Oktoechos, Rome 1520; Parakletike, Venice 1522; Triodion, Venice 1526; Euchologion, Venice 1526; Typikon, Venice 1545; Menaia, Venice 1548, cf. E. Wellesz, The History of Byzantine Music and Hymnography, ${ }^{2}$ Oxford 1998, p. 431.

${ }^{30}$ Maximus the Greek explained the meaning of the additional name borne by Apostle Paul - the Romanian - as the noble name always attained by respectfully following the ancestor, in manuscript: Moscow, Russian State Library, РГБ, 256.264, f. 68 r.).

${ }^{31}$ E. Layton, Notes on Some Printers and Publishers of $16^{\text {th }}$ Century Modern Greek Books in Venice, Thes 18, 1981, p. 120.

${ }^{32}$ Н.В. Синицына, Максим Грек..., p. 53, 83.

${ }^{33}$ Eadem, Раннее..., p. 27; еadem, Максим Грек..., p. 90. 
monastic name of Maximus (after St. Maximus the Confessor). While at the Holy Mount Athos, he continued his work with manuscripts, combining Eastern and Western sources of canonical Christian knowledge. His previous education and experience in Italy were not only considered as valid, but also quite appreciated. As a monk at the Monastery of Vatopaidi, Maximus had access to the oldest manuscripts of Mount Athos (upon request, he transcribed a damaged old manuscript that was of significant value in a dispute related to certain properties of the monasteries of Kastamonitou and Zograf). As a monk, he began studying the writings of the Holy Fathers ${ }^{34}$ of the Orthodox Church; he was also introduced to the chants of Byzantine hymnography. He embarked on a profiled translation activity, based on the Greek normative tendencies, through which Bulgarian linguistic features were soon being replaced not with Russian but with Serbian ones ${ }^{35}$. In the Athonite libraries of the Serbian Hilandar Monastery ${ }^{36}$, which housed the oldest Slavic manuscripts ${ }^{37}$, the monk Maximus was able to study the liturgical language of the South Slavs. In this period, Maximus became the closest disciple of Niphon II, Patriarch of Constantinople ${ }^{38}$, who was also appointed Metropolitan of Wallachia at that time. For Patriarch Niphon, Maximus created many texts in verse, dating to the years $1506-1516^{39}$. Moreover, it was here that he wrote the first poetic works of his own, mainly of an epigrammatic and homiletic character. He wrote the Elegiacs on the Grand Rhetor Manuel of Corinth for the Great Rhetor of the Church of Constantinople (1482-1532) ${ }^{40}$, a hymnographer and musician related to the ruler of Moldo-Vlachia, Neagoe Basarab (himself a ktitor of Constantinople and of Jerusalem ${ }^{41}$ ). Maximus also wrote the Verses on Patriarch Joachim $I^{42}$, similar in form to the biographical epitaphs popular among humanists in the middle of the $15^{\text {th }}$ century, especially in North Italy and the Western

\footnotetext{
${ }^{34}$ E. Denissoff, Maxime..., p. 27.

${ }_{35}$ В.А. Мошин, O периодизации русско-южнославянских литературных связей X-XV вв., [in:] Русь и южные славяне. Сборник статей к 100-летию со дня рождения В.А. Мошина (18941987), ed. В.М. ЗАгреБин, Санкт-Петербург 1998, р. 85.

${ }^{36}$ The Panteleimon Monastery, traditionally Russian, also housed a large number of Serbian monks at the time, Д.И. Мурешан, От второго к третьему Риму (Роль Патриархата и румынских влияний), Ори 9, 2014, р. 117.

${ }^{37}$ Cf. В.А. Мошин, О периодизации..., p. 85.

${ }^{38}$ Later, in Moscow, Maximus also mentions Patriarch Niphon II in the text About the Athonite Monasteries, in which he emphasises the principles of mutual help and common possession: In our days, there were abundant gifts of the holy Patriarch Niphon who piously passed away in this monastery and, hallowed from God was celebrated, ПреП. МАКСим Грек I, p. 124.

${ }^{39}$ ПреП. МАКСИм ГреК I, p. 102-119.

${ }^{40}$ I. ŠEvČENKo, The Four..., p. 298.

${ }^{41}$ Д.И. МурешАН, От второго..., p. 138.

${ }^{42}$ Joachim I received funerary honours from Wallachian ruler Radu the Great (d. 1508). In the years 1497/1498, he confirmed the position of Moldavian king Stephen III the Great (1433-1504) as "Protector of Athos", Д.И. МурешАн, От второго..., p. 116-117.
} 
Slavic lands ${ }^{43}$. However, from this period onwards, Maximus's poetic works were closely tied with liturgical contemplation. Beside the Verses on Martyr St. Demetrius, he also composed the complex Service-prayer to St. Erasmus of Ochrid ${ }^{44}$ with 8 odes and 8 corresponding songs, dedicated to the Virgin Mary (theotokion). The significance of the second ode and the theotokia is the connection with the Byzantine hymnography of the $7^{\text {th }}-8^{\text {th }}$ centuries, particularly the canons by St. Andrew of Crete ${ }^{45}$. The prayer, which corresponds to the supplicatory evening service (apolithykion, apostixon) as well as the night vigils (pannyxida) ${ }^{46}$, ends with a soteriological message and a final extended speech, entitled St. Erasmus' Synaxarium and signed by the author in February $1509^{47}$. In the first paragraph, Maximus reveals that he was not able to learn much about Erasmus's childhood and education, as he had to rely on severely damaged manuscripts in the course of his work on the transcript. Nevertheless, he proceeds to tell the life of the great scholar (hieromartyr) Erasmus ${ }^{48}$ in accordance with what he was able to understand from the manuscript. The latter information is extremely important in that it confirms that Maximus's work at Vatopaidi was not limited to liturgical manuscripts: he also studied hagiographic content meticulously.

Maximus's most important work while at Vatopaidi was the hymn in the form of the Intercessory Canon to St. John the Baptist ${ }^{49}$. In contrast to Romanos Melodos

\footnotetext{
${ }^{43}$ Under the influence of Aeneas Silvius Piccolomini, Johannes Rot also wrote an Epitaph for Ulrich II of Cuilli following the latter's death, P. Simoniti, Humanizem na Slovenskem in Slovenski humanisti do srede XVI. stoletja, Ljubljana 1979, p. 16-17, 239-242. Later, in Russia, Maximus the Greek translated Piccollomini's work entitled The story of the Fall of Constantinople, sharing with pope Pius II the fear for the threatened Christian knowledge after the fall of Byzantium.

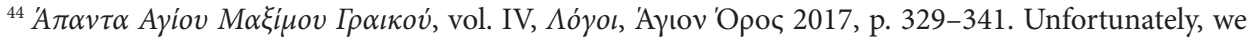
were not able to consult the original manuscript. For this reason, we quote from the present edition, although it is not considered to be critical.

${ }^{45}$ А.Ю. НикифоровА, Из истории Минеи в Византии. Гимнограбические памятники VIII-XII вв. из собрания монастыря святой Екатерины на Синае, Москва 2012, р. 183.

${ }^{46}$ Cf. ibidem, p. 287, 289, 292.

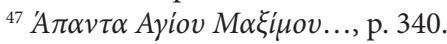

${ }^{48}$ Maximus provides a short account of the life of St. Erasmus: Hieromartyr Erasmus of Antioch suffered torments under emperor Maximian when he ruled over the territory of Illyricum. It started when Erasmus, preaching Christ's faith, toppled statues in the city of Lychnidos. The emperor sent his troops, who arrested Erasmus and brought him before his face. Trying to force him to adore other gods, he took him to the temple of Zeus, where Erasmus toppled the god's statue simply by looking at it. A giant snake crawled from under the statue. Terrified, people looked to Erasmus for help - and he baptised them. The emperor then ordered the baptised to be killed, while Erasmus was placed inside a hot bronze cage. The latter cooled down owing to God's grace, so that Erasmus survived. Subsequently, he was imprisoned, yet God again saved him. He then miraculously arrived in Campania, in the city of Phyrmos, where he

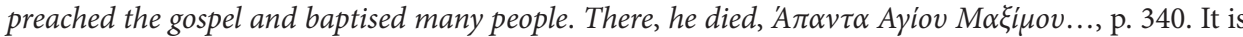
also worth noting that St. Erasmus was honoured particularly in Macedonia (Ochrid) and Albania at the time of the rule of Andronicus II. These lands were close to Arta, where Mikhail Trivolis was born.

${ }^{49}$ The Holy Mount Athos, The Holy Monastery of Vatopaidi, Cod. 1016, f. 32 r.-34 v.
} 
- who, in the $6^{\text {th }}$ century, composed a poem on the death of St. John the Baptist which contained 18 odes $^{50}$ - Maximus's canon features 8 odes with the ensuing heirmoi, associated with the liturgical realisation of the text, particularly with the feast of John the Baptist ${ }^{51}$. The odes are interpolated with verses dedicated to the Holy Mother of God. The canon also contains an overture in the form of a hymn to the Feast of the Exaltation of the Cross (the first feast after the Birth of the Holy Theotokos), and after that an ode to the Prophet John the Baptist, connected with the Feast of the Prophet and Forerunner John the Baptist on the first Sunday after Epiphany ${ }^{52}$. After the reading from Psalm 50 is found the first glorification (doxology) dedicated to the Mother of $\mathrm{God}^{53}$, whom the author implores to recognize

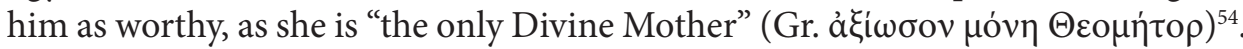
It seems that Maximus was particularly influenced by the mystagogical and theological views of Maximus the Confessor, since both authors managed to combine monastic humility with the liturgical observance of the sacred space of the church; and they did so using the language of biblical awareness (in particular, respecting the prophetic message of John the Baptist, repeated throughout the canon) ${ }^{55}$. This can be observed in the following heirmos, placed after the above-mentioned theotokion:

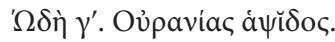

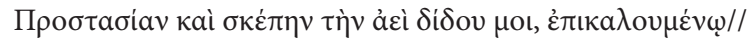

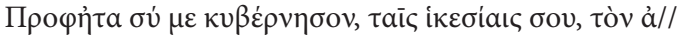

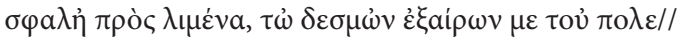

нйторос.

$4^{\text {th }}$ chant of the Heavenly Dome/Arch.

But give me your protection and cover when I call you; you steer me,

o Prophet, with your prayers, into a safe haven

liberating me from those who fight (against me $)^{56}$.

\footnotetext{
${ }^{50}$ H.J.W. Tillyard, Byzantine Music and Hymnography, London 1923, p. 14-16.

${ }^{51}$ The feasts in honour of St. John the Baptist were traditionally widely celebrated in the liturgy services of the Athonite monasteries (of the Studite tradition), cf. А.Ю. НикифоровА, Из истории..., p. 183 , an. 4 .

${ }^{52}$ Later, these verses were known as the Apolythikion of St. John the Baptist in Orthodox liturgy.

${ }^{53}$ A similar praise in honour of the Mother of God is placed after the reading from the Gospel of Matthew, The Holy Mount Athos, The Holy Monastery of Vatopaidi, Cod. 1016, f. 34 r.

${ }^{54}$ This short prayer corresponds to the theotokion from the Kanon Parakletikos Agion Parthenion by Symeon the Metaphrast, traditionally read in July before the Feast of Dormition.

${ }^{55}$ Cf. R. Bornert, Les commentaires byzantins de la divine liturgie. Du VIIe au XVe siècle, Paris 1966 [= AOC, 9], p. 86-88.

${ }^{56}$ The Holy Mount Athos, The Holy Monastery of Vatopaidi, Cod. 1016, f. 32 v.
} 
The final address in the $9^{\text {th }}$ ode is a direct and clear veneration (Kupiws $\Theta \varepsilon o \tau$ кov). Mentioning the community of God the Son and His Mother, it accomplishes the pious request with the following words:

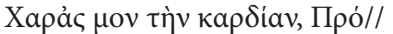

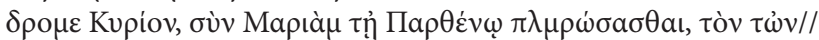

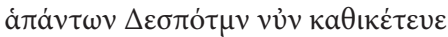
To fill my heart with joy, the Fore//
runner of the Lord, please, together with Virgin Mary,
beg the Lord ${ }^{57}$.

This passage expresses the prayer by referring to the very important Athonite

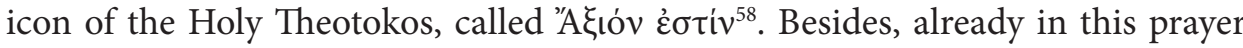
one may notice the quite special syntactic and semantic way of constructing the theological message: the repetition of similar but grammatically different words, which enhances the liturgical message of the prayer. This method can be found in the later works by Maximus the Greek as the leading principle of the structuring of his theological message and his main textual innovation.

By that time, the monk Maximus had already revised various liturgical manuscripts, since his marginalia have been found in the rare Greek manuscript of the Hagiography of Clement of Ochrid ${ }^{59}$, which also contains the liturgical service to this Slavic scholar and saint (in the Menologion for the month of November, on November $25^{\text {th }}$ ). On the occasion of Metropolitan Niphon's death, on August $11^{\text {th }}$, 1508, Maximus wrote the First Epitaph on Patriarch Niphon II, in which he used a linguistic comparison: Patriarch Niphon was called "the second Elijah", which could be explained by the fact that this saint was highly venerated among the Orthodox South Slavs. Maximus also wrote the Verses on the Reliquary of Patriarch Niphon $I I^{60}$. These facts confirm that Maximus accompanied Patriarch Niphon II on his Orthodox missions outside Mount Athos ${ }^{61}$, especially to Moldo-Vlachia ${ }^{62}$,

\footnotetext{
${ }^{57}$ The Holy Mount Athos, The Holy Monastery of Vatopaidi, Cod. 1016, f. 34 v.

${ }^{58}$ The Holy Mount Athos, The Holy Monastery of Vatopaidi, Cod. 1016, f. 34 v.

${ }^{59}$ The Holy Mount Athos, The Holy Monastery of Vatopaidi, Cod. 1134, f. 355 v., 369 v., 368 v., 368 r., 367 v., 363 r., 362 r., 362 v., 361 r., 361 v.

${ }^{60}$ I. ŠEvČENKo, On the Greek..., p. 68-69. It is worth mentioning that, in the $15^{\text {th }}$ century, the Orthodox believers of Moldo-Vlachia were a particularly crucial element of the intermediate intellectual exchange between Serbia and Russia (including Southern Russia and Ukraine), В.А. Мошин, O периодизации..., p. 96. Moreover, Moldo-Vlachia had a significant role in the political and ecclesiastical organization of the Orthodox Patriarchate, particularly between Moscow and Constaninople, Д.И. МурешАН, От второго..., p. 117-118.

${ }^{61}$ During such Orthodox missions, where all members would not speak the various national languages, Latin was used as the language of diplomacy (Humanist Educational Treatises, trans. C.W. KALLENDORF, Cambridge Massachusetts-London 2008 [= TRL], p. 87), as was common at European imperial courts at the time.

${ }^{62}$ I. ŠEvČEnko, On the Greek..., p. 63-64; E. Denissoff, Maxime..., p. 321-329.
} 
which was later described in Maximus's letter to Russian Metropolitan Makarius ${ }^{63}$. After ten years of monastic life at Mount Athos, Maximus - as an experienced scribe with linguistic skills - was chosen for a mission to Russia. Thus, in 1516, he was sent to Russia as a translator (from Greek to Church Slavic) and editor of liturgical books, as part of a new Orthodox mission that was sent as a response to the request made by Vasili III, Grand Prince of Moscow. On his journey to Moscow, Maximus was accompanied by one Bulgarian and one Russian monk ${ }^{64}$. Moreover, the above-mentioned verses dedicated to Patriarch Niphon confirm that, while on his way to Moscow as part of the Athonite delegation ${ }^{65}$, he stopped in the Wallachian city of Curtea de Argesi, where the holy relics of Patriarch Niphon II were transferred in 1517. Maximus probably also passed through Constantinople. Besides, he most certainly stopped in Venice, where he had some old acquaintances; in addition, it was only there that he could acquire the Greek books that he would need for his future work with liturgical manuscripts in Russia. Thus, it is worth pointing out that exactly at that time Venice saw the rise of liturgical printing for South Slavic Orthodox believers, in the printing house of Božidar and Vincenzo Vuković; this occurred in two phases (in 1518/1519 and in 1546/1547, respectively). This was the first time when Maximus purposefully focused on the study of the Slavic language(s), which can be explained not only by the above-mentioned contacts with Wallachian and other Eastern Christian ecclesiastical centres, but also by the vicinity of the northern Italian cities - particularly Venice - to the Slavic lands.

Soon after his arrival in Moscow in 1518, Maksim Grek - as he was called in Russia -translated the first part of the Apostol ${ }^{66}$ (the Acts, completed in 1519), and in 1520 also the second part (the Apostolic Letters) ${ }^{67}$. In 1522, he fini-

${ }^{63}$ In this letter (cf. the manuscript from Paris, Bibliothèque Nationale (BN), Slav. 123, f. 79 r.), Maximus explicitly reports that he had already preached the Orthodox theological principles to "the Noble Lachs" (i.e. Italian Catholics or Moldo-Vlachians) before his arrival to Moscow, in places where the Nomocanon of the Patriarch Photius had been regula legis for a long time, J.-B. Pitra, Des Canons et des collections canoniques de l'Église Grecque, p. 63, an. 3. He then continues: I was sent from the Holy Monastery of Vatopaidi to preach the pure Orthodox faith and I did so with the holy support and the inspiration of the Divine Paraclete, and from everywhere I was deliberately returned to the Holy Mount Athos, but nowhere did it happen to me like here, in Russia, where I was put into iron chains, and I experienced in a dark cell the cold, the smoke, and starving, Paris, Bibliothèque Nationale (BN), Slav. 123, f. 79 r.

${ }^{64}$ Notably, it has been proposed that Maximus learned the Slavic language not with the help of Greek, but Latin, S. Runciman, The Great Church in Captivity. A Study of the Patriarchate of Constantinople from the Eve of the Turkish Conquest to the Greek War of Independence, London 1968, p. 327; И.В. Ягич, Рассуждения южнославянской и русской старины о церковнославянском языке, Санкт-Петербург 1896, p. 301, 306.

${ }^{65}$ I. Š EvČEnKo, The Four..., p. 299, 304; Д.И. МурешАн, Om второго..., p. 117-118.

${ }^{66}$ Н.В. Синицына, Максим Грек в России, Москва 1977, р. 64.

${ }^{67}$ The only version from $16^{\text {th }}$ century is in Moscow, State Historical Museum, ГИМ, Муз. 3475; А.И. ИванОв, Литературное..., р. 47. 
shed ${ }^{68}$ the translation of the extensive Annotated Psalter ${ }^{69}$, with copious notes that expanded the manuscript into 1042 pages. It was Maximus the Greek's translation of the Annotated Psalter that first appeared in Russian Church Slavic. When in 1522 Daniil became Metropolitan of Moscow, he asked Maximus to translate for him the Ecclesiastical History by St. Theodoret from Cyrrhus; he refused, aware of the theologically complex content that could have led to misunderstandings. But he never suspected that this rejection would almost cost him his life. In 1525, at the Moscow Church synod, he was for the first time accused of purported heretical translation errors in Russian liturgical manuscript books. As a result, he was imprisoned in the Joseph Volokolamsk Monastery. A minor linguistic misunderstanding ${ }^{70}$ between the political body of the Russian church and Maximus the Greek was the official reason for even more serious accusations against him. Consequently, he was excommunicated and not allowed to attend Church service (the Divine Liturgy), to communicate, to have or read books ${ }^{71}$, as well as to write. Maximus was put into irons and barred from the Sacrament of the Holy Communion/Eucharist - the harshest thinkable punishment for an Orthodox monk. In May 1531, the charges against him were renewed. This time, he was accused of several transgressions, including that he was a spy for the Islamic court. Two of his translations of letters were also deemed problematic: pope Pius II's letter to Mehmed II, or the story about the fall of Constantinople by Aeneas Silvius Piccolomini $^{72}$, as well as the letter of Suleiman the Magnificent to Marino Grimani, doge of Venice ${ }^{73}$ - an ardent persecutor of Protestant teaching in the Northern Slavic lands ${ }^{74}$. In addition, he was accused of having committed heretical errors in the translation of the hagiographic text of the Life of Mother of God from the Hagiographic Collection-Menologion of Symeon the Logothete (Metaphrast). After ten years of imprisonment, under metropolitan Joasaphus, he was transferred (probably in the autumn of 1536) from the Joseph Volokolamsk Monastery to the Otroch

${ }^{68}$ Н.В. Синицына, Новые данные о российском периоде жизни преподобного Максима Грека (материаль для научной биографии), ВЦИ 4, 2006, р. 222.

${ }^{69}$ Moscow, State Historical Museum, ГИМ, Щук. 4. In this manuscript, it counted 789 pages.

${ }^{70}$ Б.А. УСпенский, История русского титературного языка (XI-XVII вв.), ${ }^{3}$ Москва 2002, p. 234-235.

${ }^{71}$ Судные списки Максима Грека и Исака Собаки, еd. Н.Н. Покровский, Москва 1971, p. 55, fol. $344 \mathrm{v}$.

${ }^{72}$ The Story of the Turkish Capture of Constantinople by Enea Silvio Piccolomini (pope Pius II), in which the pope - setting out for a new Crusade against the Turks - addresses Sultan Mehmed II the Conqueror, challenging him to accept the Christian faith. The letter was considered lost, but preserved only in this translation: Moscow, State Historical Museum, ГИМ, Син. 791. Н.В. СиницынА, Археограбический обзор, [in:] ПреПодОБНЫЙ МАКСИм ГРек, Сочинения, vol. I..., p. 522; ЕADEм, Творчество преподобного Максима Грека 30-50 гг. XVI в. и собрание избранных сочинений из 47 глав, [in:] ПреПодоБНЫЙ МАКсим ГРек, Сочинения, vol. II, Москва 2014, p. 24; В.Ф. РЖИГА, Кто перевел краткую повесть о взятии Константинополя турками, Sla 13.1, 1934, p. 105-108.

${ }^{73}$ Н.В. Синицына, Археографический..., р. 522.

${ }^{74}$ P. Simoniti, Humanizem..., p. 88, an. 25. 
Monastery in Tver. This time, the circumstances of his imprisonment became slightly milder in that he was at least allowed to write ${ }^{75}$. With the fall of Daniil, after 1547, Maximus's position improved. In 1552 (following the Stoglav of 1551) ${ }^{76}$, he found a new home in the Trinity Lavra of St. Sergius. That year, he also managed to send his two poems in Greek to the Western European countries (they also exist in his Slavic version). Maximus the Greek died in the Trinity Lavra of St. Sergius in 1556. On January $21^{\text {st }}$, he was consecrated at the memorial day of St. Maximus the Confessor. In 1986 this day was finally dedicated to St. Maximus the Greek and he was included among the Orthodox saints by an official confirmation of the Russian Church.

\section{Maximus's Philological, Theological and Liturgical Contributions}

Maximus wrote a wide range of works in Church Slavic, which may be defined most appropriately as theological writings; he re-edited them several times in his final years, adding corrections and assembling them three times. To the three lifetime "Russian" collections of works could be added the collection of his selected works preserved in Paris (Paris, Bibliothèque nationale (BN), Slav. 123) ${ }^{77}$, presenting an intermediate image - i.e. between the Iosif and Chludov collections (two lifetime collections of the works by St. Maximus the $\mathrm{Greek}^{78}$ ). This manuscript volume, representing a very rich selection of his works ${ }^{79}$, also contains the reflection of an archetype manuscript that is not extant in the known Russian collections ${ }^{80}$; it has been suggested that some materials from the author's personal archive were preserved there. But none of the manuscripts written entirely by the hand of Maximus the Greek in Slavic have been preserved: all of his Slavic manuscripts were copied or supposed to be written under his dictation. The only material identified as his original handwriting is preserved in the marginalia, comprising various interventions and commentaries ${ }^{81}$. Beside his Slavic texts, some of his Greek manuscripts are extant, as are his letters and some of his notes in Latin ${ }^{82}$.

\footnotetext{
${ }^{75}$ Н.В. Синицына, Новые..., p. 224-225.

${ }^{76}$ Sinitsyna also mentions the date $1548 / 1549$ as the year of the third attempt of the trial against him, Н.В. Синицына, Творчество..., p. 18.

${ }^{77}$ Unfortunately, we were not able to access the published version of this edition (Moscow 2017); however, the Russian scholars from the Institute of History (Moscow, RAN) notified us that it was obviously based on a most problematic copy of the manuscript, as a result of which the published version contains a large number of mistakes and dubious readings. For this reason, we are relying on the original manuscript [N.Z.].

${ }^{78}$ Cf. Н.В. Синицына, Творчество..., p. 34-40.

${ }^{79}$ The version published in Moscow in 2017 is inadequate in view of the numerous misprints and problematic readings, $\mathrm{cf}$. above.

${ }^{80}$ This information was discussed and confirmed in a conversation with Nina Vasilevna Sinitsyna in April 2103 [N.Z.].

${ }^{81}$ Б.Л. Фонкич, Новый..., p. 74-79.

${ }^{82}$ The front cover of the letter to Carteromach, E. Denissoff, Maxime..., plate VII.
} 
If in his early texts Maximus fought vehemently against the Latin modification of the Creed of the Christian faith (the addition of the controversial filioque) ${ }^{83}$, his texts from the later period were secretly permeated with his objections to the diminution of the holiness of the Mother of God. He also emphasized the heretical mistakes in the Russian manuscripts, essentially those that contradicted Orthodox theology and the pure glory of the Mother of God; paradoxically, during his second trial in Moscow, he was accused of the very same offence. His translation of the Annotated Psalter contained an extended patristic interpretation of the nine biblical canticles ${ }^{84}$, following the readings of the 150 psalms. Among these, one can find a detailed interpretation of the Song of Mary, known in the Western liturgical tradition as the Magnificat (based on the evangelical verses in Lc 1, 46-55), which Maximus summarises as expressing glory to the Son of God ${ }^{85}$ (furthermore, he connects the message of this song with the cosmographical hierarchy in accordance with the theological views of Gregory of Nazianzus). At this time, Maximus was obviously introducing a particular understanding of the principal theological unity (inherent alliance, essential non-separability) of Mary and God the Son, which he later expressed more clearly from the theological point of view - namely, in his argumentation on the Holy Trinity (Mary as the one responsible for the incarnation/birth of Christ/Word). This is a topic that Maximus indirectly - though persistently - attempted to clarify when working with Russian clerics and monks, as can be seen through a close reading of his text The Confessional Creed of the Orthodox Faith. Moreover, this can be confirmed in the theological doctrine only by the refusal of the addition to the Confessional Creed of the Latin filioque, and this partly explains Maximus's constant polemics against Catholicism.

\footnotetext{
${ }^{83}$ The controversial addition to the Creed, also connected with the "new" teaching, is associated with certain beliefs concerning the proceeding of the Holy Spirit. In particular, it claims that the Holy Spirit proceeds not only from God the Father, but also from God the Son. It began to spread through the Christian West during the rule of Charlemagne (in the year 802), when this kind of thought (based on the Augustinian Trinitarian doctrine) appeared in the teachings of Alcuin of York, E.A. SIECIENSKI, The Filioque. A History of a Doctrinal Controvers, New York-Oxford 2010, p. 95. In fact, Greek theologians rejected the innovation mainly because it deprived the liturgical act of the epiklesis (the Greek practice of a prayer invoking the Holy Ghost at the consecration of the Host) - a prayer which the Latins omitted from then on, S. Runciman, The Last Byzantine Renaissance, London 1970, p. 37.

$\left.{ }^{84} 1-2\right)$ the two song-prayers of Moses (Ex 15, 1-19; Dt 32, 1-43); 3) the prayer of the prophetess Hannah (1Sam 2, 1-10); 4) the prayer of Habakkuk (Hab 3, 2-19); 5) the prayer of Isaiah (Is 26, 9-19); 6) the prayer of Jonah (Ion 2, 2-19); 7) the prayer of Azariah (Dn 3, 26-45); 8) the song of the three Holy children (Dn 3, 52-88); 9) the song of Mary (Lc 1, 46-55), Г.М. Прохоров, “Так воссияют праведники...”. Византийская литература XIV в. в Древней Руси, Санкт-Петербург 2009, p. 131. Additionally, in the Old Testament one may also find other song-prayers, which all display the syllabic rhythmical principle, an assonance, and an acrostic, U. CHevalier, Poésie liturgique du Moyen Âge, Paris-Lyon 1893, p. 9, 11: the prayer of Salomon (2Par 6, 14.18-21.40-42); 1Par 16, 8-36; Is $26,9-20$; Is $38,10-20$; Is $42,10-13$; Ier $10,6-16$; Ier $17,5-18$ etc.)

${ }^{85}$ Moscow, State Historical Museum, ГИМ, Щук. 4, f. 794 r.
} 
Maximus's interpretation of the Magnificat follows the hierarchically cosmographical view from the theology of Gregory of Nazianzus, but also shows his own affiliation, which led to his ideas about the goodness of earthly life and the virtue of human creation. Maximus specifically connects the message of this liturgical song with the idea of God's benevolent love of humankind, as seen in the words with which he concluded his second translation of the Liturgical Psalter in 1552 (four years before his death). In Maximus's opinion, the highest example of the purest Divine inspiration was the translation endeavour of the Septuagint - also one of the first examples of a bilingual translation process - which he mostly followed. The analysis of Maximus's language in the Psalms (1552) ${ }^{86}$ suggests that he knew the first Greek-Latin Psalter, published in Milan on September 20 ${ }^{\text {th }}$, 1481 (a copy that contains notes on the margins was also preserved in Russia, today in St. Petersburg) ${ }^{87}$, in which the editor Giovanni Crastone critically corrected the previous Latin edition of St. Hieronymus ${ }^{88}$ on the basis of a comparison with the Greek Septuagint $^{89}$, as the author explains in the Preface. The comparison of the most significant replacements introduced by Crastone ${ }^{90}$ and Maximus's second editing of the language of the Liturgical Psalter $(1552)^{91}$ shows that Maximus considered both versions of the Psalter (Greek and Latin) ${ }^{92}$, on the basis of which he selected the Slavic word. But unlike Crastone, Maximus the Greek paid great attention to the liturgical meanings of the relevant word combinations, which confirms

\footnotetext{
${ }^{86}$ Moscow, State Historical Museum, ГИМ, Увар. 15/85.

${ }^{87}$ А.Х. Горфункель, Миланская Псалтирь Джованни Крастоне 1481 г. и гуманистическая критика Библии, [in:] Коллекиии. Книги. Автограбы, 2, Книжные редкости Публичной библиотеки, Ленинград 1991, p. 40.

${ }^{88}$ The Parallel Greek, Hebrew and Latin text was reproduced in the (pseudo-)Aldine, 1518. This edition has been the most frequently mentioned as the one that Maximus the Greek took to Moscow (Venice, Aldo Manuzio 1494), С. БЕлокуров, О библиотеке московских государей в XVI столетии, Москва 1899, p. 302-304.

${ }^{89}$ This publication was presumably not intended for a Greek but for a Latin readership, specifically for Latin monks who wanted to learn Biblical Greek, cf. E. LAYTon, Notes..., p. 120, an. 4; А.Х. Горфункель, Миланская..., р. 35.

${ }^{90}$ Ps 5, 4; Ps 16, 2; Ps 31, 2; Ps 39, 7; Ps 86, 5; Ps 131, 15; Ps 138, 4, А.Х. Горфункель, Миланская..., p. 36-37. The first Russian printed edition of the Bible (the Bible of Ostrog), published by Ivan Fyodorov, was closer to the Septuagint and the Aldine Bible. The Synodical Russian Psalter mostly agrees with the Vulgate and the Masoretic version of the Book of Psalms. For Maximus the Greek's indirect motivation for the establishment of the Print Yard in Moscow see F.J. Thomson, The Slavonic Translation of the Old Testament, [in:] The Interpretation of the Bible. The International Symposium in Slovenia, ed. J. Krasovec, Sheffield-Ljubljana 1998 [= JSOT.SS, 289], p. 108-112.

${ }^{91}$ Moscow, State Historical Museum, ГИМ, Увар. 15/85. Сf. И.В. Вернер, К истории перевода Псалтыри Максимом Греком в 1522-1552 годах: хронология, текстология, методология, Слав 2, 2017, р. 45-46.

${ }_{92}$ И.В. Вернер, Грамматическая справа Максима Грека в Псалтыри 1552 г., [in:] Письменность, литература, фольклор славянских народов. История славистики, ХV Международный съезд славистов, Москва 2013, р. 108, 110, 113.
} 
his awareness of the complex biblical linguistic message. Crastone's words in the Preface concerning the errors of previous translators ${ }^{93}$ are close to Maximus's argumentation about the Holy Grammar. Indeed, Maximus also understood the knowledge of Slavic in terms of strict criticism $^{94}$ - this is an issue which he explains several times in his manuscripts. It is expressed clearly in his writing entitled The Treatise of the Monk Maximus about Correcting the Russian Books, and Against Those Who Speak that the Body of Lord after the Resurrection became indescribable, in which Maximus explained the manner in which he dealt with the Russian liturgical book (Triodion):

I do not corrupt Russian books, as I was falsely accused, but take great care in my fear of God to correct, with my common sense, what has spread from inept copyists, unfamiliar with the holy grammar - or from the first translators of the Holy texts. Truth must be told. Sometimes the gist of Hellenic sayings was not fully apprehended, which led to steering away from the truth. Hellenic speech is often difficult to interpret; those who do not learn its grammar, poetry and above all philosophy, cannot clearly understand what was written, let alone translate it. The truth must be told that I carefully and diligently corrected what they misunderstood, the same must be explained to your Excellency with all honesty, in front of whom I humble myself as before God. Let me start with the following. I took the holy book of Triodion and noticed in the $9^{\text {th }}$ hymn of the Maundy Thursday Canon: 'In His nature non-created Son and Word of the Father Who is always without the beginning, Who is not in His nature non-created, as they sing about Him'. I could not stand this great insult, so I amended the injury, as was handed to us by the most sublime Paraclete through the most blessed Kosmas in our books. ${ }^{95}$

Moreover, it is clear that Maximus the Greek considered the knowledge of the language - of Greek, and especially the language of the Bible - literally as Holy Wisdom ("the Holy Grammar"); consequently, his reception of Slavic grammar was likewise marked with a significant theological dimension ${ }^{96}$. Certainly, Maximus's use of the Slavic language was invariably intentional. It is clear that Maximus the Greek was also close to the philological group that assembled the bilingual (Greek-Latin) material for the Lexicon published by Manuzio and edited by Crastone in Milan in 1478. Between the preface and the core part of the lexicon, we find two epigrams with a praise to Manuzio. The authors were Scipio Carteromach and Marco Musuros, two of Mikhail Trivolis's companions and members of the second wave of Greek diaspora; in the verses, they expressed their longing for home and their wish to cultivate their mother tongue of Greek ${ }^{97}$.

${ }^{93}$ А.Х. ГОРфУнКель, Миланская..., р. 34.

${ }^{94}$ И.В. Ягич, Рассуждения..., р. 301, 306.

${ }^{95}$ Paris, Bibliothèque Nationale (BN), Slav. 123, f. 259 v.-260 r.

${ }^{96}$ N. ZAJC, Some Notes on the Life and Works of Maxim the Greek (Michael Trivolis, ca 1470 - Maksim Grek, 1555/1556). Part 2: Maxim the Greek's Slavic Idiolect, Scri 12, 2016, p. 380-382.

${ }^{97}$ The two epigrams translate as follows. Scipio Carteromach: Upon the strangers who seek,// This book bestows many flowers of the Hellenic tongue,//Like a meadow. For the Latin-speaking, it keeps many 
However, the process of Maximus the Greek's translation endeavours in Russia was initially realized through the mediation of Russian translators, Dmitri Gerasimov and Vlas, with the aid of the scribe Mikhail Medovartsev ${ }^{98}$. Maximus would translate expressions from Greek and provide the relevant phrases in Latin, whereas they would translate them into the Russian recension of the Church Slavic language. As regards the latter, Maximus followed a particular usage of verbal forms, which did not change until the end of his life in Russia. Namely, he used the perfect form ( $l$-form plus copula of the verb "to be") instead of the traditional aorist, which left the Russian clerics with the impression that he did not refer to the eternal meaning of the Saviour. In fact, while such a linguistic difference was absent from the spoken Russian language of the time, it did exist in the $15^{\text {th }} / 16^{\text {th }}$-century spoken ${ }^{99}$ literary language (which was considered the same as the liturgical one) of those South Slavic nations that were geographically close to or in contact with Latin liturgy ${ }^{100}$ (Slovene, Croatian ${ }^{101}-$ the Slavic languages of the Christian milieu spoken in close proximity of the northern Italian lands). Additionally, it could be noted that this kind of verbal form (without copula $)^{102}$ may have been familiar to Maximus from his native places, because Arta bordered on the Macedonian-Albanian territory, where such forms were used frequently (especially with transitive verbs) in the everyday spoken varieties of the local Slavic dialects from the $9^{\text {th }}$ century onwards ${ }^{103}$. But through that linguistic difference - the copula - Maximus introduced into the Russian (Church Slavic) language a new distinction (as found e.g. in Latin), namely between the $2^{\text {nd }}$ and the $3^{\text {rd }}$ person singular perfect. The effect was a verbal form that could be

treasures,//And Aldus made a great effort in making it very handy. Marcos Musuros of Crete: When the Pelasgian tongue and the Ausonian daughter [an allusion to Latin - N.Z.]// Came into strife about the origin of the book,// Aldus, giving it a thought, saw that it was undecided,// So he decided it to be common to them both.

${ }^{98}$ Moscow, State Historical Museum, ГИМ, Щук. 4, f. 1 v.; Судные списки Максима Грека и Исака Собаки, p. 104-107.

${ }_{99}$ Cf. Е.В. КРАвЕц, Книжная справа и переводы Максима Грека как опыт нормализации церковнославянского языка XVI века, RLin 15, 1991, p. 252.

${ }^{100}$ Note that the parallel linguistic experience within the Latin liturgy did not cause any interference between the relevant languages.

${ }^{101}$ B. HavraneK, Aspects et temps du verbe en vieux slave, [in:] Mélanges de linguistique offerts à Charles Bally sous les auspices de la Faculté des lettres de l'Université de Genève par des collègues, des confrères, des disciples reconnaissants, Genève 1939, p. 223-230.

${ }^{102}$ Cf. A.N. SoвоLev, Hybrid Grammar in a Macedonian Dialect from Albania, [in:] Индоевропейское языкознание и классическая филология - ХХІІ (чтения памяти И.М. Тронского). Материаль Международной конференции, проходившей 18-20 июня 2018 г., pars 2, (c. 795-1486), ed. Н.Н. КАЗАНСКиЙ, Санкт Петербург 2018, р. 1252.

${ }^{103}$ А.Л. МАкарова, Македонский ESSE-перфект: Эволюиия формы, [in:] Индоевропейское языкознание и классическая филология-ХХІІ (чтения памяти И.М. Тронского). Материаль Международной конферениии, проходивщей 18-20 июня 2018 г., pars 2, ed. Н.Н. КАзАнский, Санкт Петербург 2018, p. 822. 
used for direct addressing $(-л+$ еси). Undoubtedly, he introduced this innovation in Russian intentionally, especially because of the theological purpose of address-

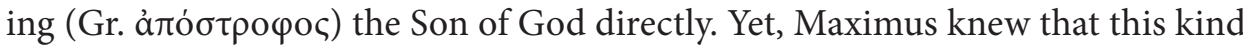
of addressing had already existed in Slavic: he could have heard it in the years before he left Venice for Mount Athos (1502-1504) or during his travel from Athos to Russia, when he might have stopped in Venice (in 1517) and nearby. In these areas, members of the Croatian Glagolitic community as well as Slovene and Serbian monks were found in quite large numbers.

Maximus the Greek translated the Hagiographic Life of the Mother of God from Metaphrast's Menologion ${ }^{104}$ already in 1521. It was an apology of Her untouched nature, which could not be expressed in earthly terms; thus, he underlined the important patristic views along with extensive biblical references (canonical and non-canonical - for example, rejecting the information from the Infancy Gospel of Thomas), as well as some less known patristic sources (e.g. Juvenal of Jerusalem, who was a great opponent of Nestorius ${ }^{105}$ ). Maximus certainly referred to pre-Metaphrast editions ${ }^{106}$, and his translation shows traces of the text entitled The Life of the Virgin, attributed to Maximus the Confessor ${ }^{107}$ and preserved until today only in Georgian translation in an Athonite manuscript. The manuscript of the Hagiography of the Mother of God ${ }^{108}$ in the translation by Maximus the Greek in the original form (i.e. containing uncorrected words related to the second trial in $1531^{109}$ ) still shows Maximus's corrections of certain words (possibly in his own hand $)^{110}$. Despite that, it offers an insight into his translation process. Maximus's method of translating was substantially different from the earlier (Cyrillo-Methodian) practice of translating texts into Slavic. Rather than operating on a word-by-word basis, it followed a sentence-by-sentence procedure (or word-byword in a theological context), where the guiding principle of translation was idiomatic usage, according to phrases and combinations of words.

\footnotetext{
${ }^{104}$ Menologii anonymi Byzantini saeculi X quae supersunt. Fasciculos duos sumptibus Caesareae Academiae Scientiarum e Codice Mosquensi 376 Vlad, ed. V.V. LATYšEv, Leipzig 1970 [= SBLOI, 12], p. 347-383.

${ }^{105}$ In his polemical writings, Maximus the Greek strongly rejected the Christian heresies - not only those known as the first Christian heresies (Arians, Nestorians, Macedonians, Eutychians), but also e.g. Judaizers, Persians, Muslims, or Armenians, D. ČIževskij, History of Russian Literature. From the Eleventh Century to the End of the Baroque, S-Gravenhage 1960, p. 298.

${ }^{106}$ S.J. Shommaker, The Georgian Life of the Virgin attributed to Maximus the Confessor: Its Authenticity(?) and Importance, Scri 2, 2006, p. 307-328.

${ }^{107}$ Maximus the Confessor, The Life of the Virgin, trans. et ed. S.J. Shoemaker, New HavenLondon 2012.

${ }^{108}$ Sankt Petersburg, Russian National Library, РНБ, Сoф. 1498, f. 119-160 v.

109 The corrections can be seen in the manuscripts: Moscow, Russian State Library, РГБ, 113.544, f. 3, 5, 5v; Н.В. Синицына, Книжный мастер Михаил Медовариев, [in:] Древнерусское искусство. Рукописная книга, Москва 1972, p. 314-317.

${ }^{110}$ Starting on page $132 \mathrm{r}$. in the manuscript, further also on the margins.
} 
Maximus's language was dominated by the effort to find correspondences with Greek grammatical constructions, due to his wish to achieve full accordance with Greek grammatical categories. His translation principles show that he combined the two oldest grammatical traditions: the Greek and Latin contributions that integrated the most ancient Greek syntactical foundations of language (Apollonius Dyscolus) with the Byzantine morphological literary context and the Latin syntactical definitions of grammatical categories (Donatus, Priscian). Moreover, it can be detected that he also combined two different methods of translation, known from biblical and sacred texts. The manuscript of the Hagiography of the Mother of God suggests that Maximus translated the original Greek text into Slavic respecting the special prepositional order of Greek - one that reflected the language's morphological ability to express the main grammatical categories - more than the principle of syntax as known at that time in the West ${ }^{111}$. The repetition of words with the same linguistic (not always equivalent with etymological) root was necessary for him in order to achieve the parallel effect of literary forms and hagiographical as well as theological content ${ }^{112}$. Through the simultaneous ramification of selected words, it was possible to stress the liturgical reception of the text (the repetition of the basic semantic core of the word enhanced the theological meaning). Maximus the Greek also utilized this method of textual formation of the theological and liturgical sense of the text in his personal writings in the later periods; it combined his translation practice and his own grammatical investigations in Slavic. Through the creation of antithetical terms, he touched upon the anthropological level of literary acceptance, which was deliberated by the achievement of the spiritual progress that was finally revealed. Such a method was especially appropriate in the process of translating poetic devices; in effect, the desired effect of the phonetical echo of Maximus's constant prayer was achieved. Indeed, Maximus's own forms of Slavic reflected a certain translation practice already in the first period: he did not translate forms directly, but as compounds, which could be a sign of a previous comparison of a given word's meaning with the Latin one at the first level of the translation project. If he would at first submit words to Russian translators in Latin, one may surmise that very soon, after 1520, Maximus was fully competent to dictate to a given Russian/Slavic scribe in Slavic.

\footnotetext{
${ }^{111}$ R.H. Robins, The Byzantine Grammarians. Their Place in History, Berlin-New York 1993, p. 32.

${ }^{112}$ For example, in the manuscript of The Hagiography of the Mother of God [repetitions are marked in normal font - N.Z.]: Вездю бо божественых еваггелии мати она по неизреченном рожении пресвптлп же и истиннп именуется [...] и отнудь недомыслено обртоти инако ту именуему (РНБ, Соф. 1498, f. 142v.); тпмже ниже множачшаа чюдеса воскресениа случися тпюғ видюти, она же неоттрбже ныне близб гробу приспдащци, зряще вся явп [...] всяя яко имяме извтьстнп виде, еже ниже мало якоже рпхомь отступити от гроба, дондеже и живоносное виде воскресение [...] види же ся убо прввпи датися и благовещения и воскресениа, и яко мощзо зрителници Еи быти Сыновня свпттости (РНБ, Соф. 1498, f. 143).
} 
Maximus would conclude his translation and writing process by a critical reading of the scribe's text; he would insert corrections and commentaries on the margins of the manuscript pages ${ }^{113}$.

Maximus propagated arguments concerning the holiness of Mary, known to him from the Hagiography of Mother of God, in his further theological works and in his confessional writings. In the text Against Those Who are Blemishing the Holiness of the Mother of God $d^{114}$ he applied to the Holy Virgin a language taken from the Mosaic law (including the snake of Moses). He made use of Old Testament metaphorical predictions from the psalms (Ps 31, 4; Ps 44, 10; Ps 44, 11; Ps 44, 14; Ps 45, 5-6; Ps 67, 16-17; Ps 109, 3; Ps 81, 1; Ps 88, 37-38) as well the vision of Isaiah in the desert (Is 11, 1); he considered the type of Mother of God as the non-burning Bush (Ex 3,1-6), also known from the First Ode of the poetic Christmas Canon of St. John of Damascus ${ }^{115}$, as well as the pre-echoes in certain female characters of the Old Testament (Esther, Leah, Mariam, etc.) as the biblical prophetical testimony of the Holy Virgin, but also references to apostolic speech. Maximus's most innovative gesture expressed the presence of the Mother of God as the link between the two Covenants. He used in his writings inserted pieces of Byzantine hymnography: the Ladder of St. James as the confirmation of the Holy being of Mary, and the first heirmos of the third canticle (the second tone ${ }^{116}$ ) from the Sunday Matins after the first reading of the Liturgical Psalter, associated with the Feast of Apostle John the Theologian $\left(26^{\text {th }}\right.$ September $)$ and making use of a significant Greek symbol of the lily (Gr. kriin) - which, according to Maximus's words, adequately symbolizes the Trinitarian purpose of the Holy Mother of God. He defines this kind of theological recognition as "the language of the Holy Scripture". Through this, he connects the liturgical and hagiographical tradition of the Feast of Dormition (in the verse of Christ's invitation to His Mother: Come, and be my bride; Angels were frightened, seeing how the Lord is carrying in His hand the soul of a woman) and points out the areas where the canonical Christian knowledge ${ }^{117}$ of the holiness of the Mother of God was established and preserved. This occurred in the Orthodox poetic prayers of the early Christian, especially

\footnotetext{
${ }^{113}$ The translation process described here is connected with the editorial and philological activity familiar to Maximus from the Florentine period, during which he collaborated with Iannos Laskaris. Thus, editing and correcting the text was only one of the Renaissance methods of dealing with Greek manuscripts and first printings.

${ }^{114}$ Paris, Bibliothèque Nationale (BN), Slav. 123, f. 125 r.-129 r.; Л.И. ЖуровА, Авторский текст Максима Грека. Рукописная и литературная традиции, pars 2, Сочинения, Новосибирск 2011, p. $172-182$.

${ }^{115}$ E. Lash, Biblical Interpretation in Worship, [in:] Orthodox Christian Theology, ed. M.B. Cunningham, E. Theokritoff, Cambridge 2008 [= CCRe], p. 45.

${ }^{116} \mathrm{Cf}$. The desert, the barren church of the gentiles, blossomed as a lily at your coming, Lord.

${ }^{117}$ On the basis of his critical principles, Maximus the Greek offered a successful critique of certain apocrypha which were among the most problematic and incompetent (e.g. the Tale of Aphroditian, a Bogomil writing), D. ČIžEvsKIJ, History..., p. 298.
} 
Eastern, patristic theologians in Byzantine hymnography, in liturgical odes from which the unique knowledge about the life of Mary as the Holy Theotokos was preserved $^{118}$. Such inclusion of the Theotokos could be found in the contemplation of Gregory of Nyssa about the Song of Songs, where he recognized the Mother of God as the Church of Christ ${ }^{119}$, but also in the poetic vision of Ambrose of Mila regarding the female figure of the Holy Scripture. The latter author is considered one of the founders of Western hymnography under Byzantine influence ${ }^{120}$; he also had a place in the writings of Maximus the Greek, who named him the "miraculous Arch-priest of God"121.

In particular, Maximus directly connected the belief concerning the timelessness of Her presence with the endless presence of Christ the Redeemer - both progressed in individual prayers. The long, poetic Prayer on Dormition attributed to Symeon the Metaphrast, which Maximus translated in Russia, also presents the principal connection of the Holy Theotokos and the Holy Trinity: Be joyful, you, the fortress of my evangelical deed, rewarmed by unshaken hopes, you who are the co-partner [co-promiser ${ }^{122}$, co-adviser] of the unspeakable consultations, you, the only woman that deserves the respect of the three shines of the Holy Trinity ${ }^{123}$. It must be stressed that Maximus the Greek clearly expressed such addition of the Holy Mother of God to the statement of the Orthodox Trinity in his Confessional Creed of the Orthodox Faith, in the following words:

I also believe and confess always essential the Son and God the Word without beginning and born from God the Father without beginning and with the spreading grace and glorified act of the Holy Spirit in the most pure nature [being] of the most Holy, and the most Virgin Mary, the Mother of God [...] Additionally I confess and am preaching myself and every pious man, the most blessing Empress of mine, the Holy Theotokos, the intercessor and the mediator of all Orthodox Christians, all perfectly saintly and the most pure and the most untouchable and the through-out all-Virgin. ${ }^{124}$

\footnotetext{
${ }^{118}$ See W. Kallistos, The Final Mystery: the Dormition of the Holy Virgin in Orthodox Worship, [in:] Mary for Time and Eternity, ed. W.M. McLaughlin, J. Pinnock, Leominster 2007, p. 250.

${ }^{119}$ A. Louth, 'From Beginning to Beginning': Endless Spiritual Progress in St Gregory of Nyssa. Lecture at the XXI Conference on the Orthodox Spirituality, [in:] The Proceedings of the XXI International Ecumenical Conference on Orthodox spirituality "The Ages of the Spiritual Life", ed. E. BiAnchi, Bose 2014.

${ }^{120}$ E. Wellesz, The History..., p. 43.

${ }^{121}$ ПреПОДОБНЫЙ МАКСИм ГРек, Сочинения, vol. II... (cetera: ПреП. МАКСИм ГРек II), p. 270.

${ }^{122}$ Cf. Gr. Kolvwvó $($ Lc 5, 10).

${ }^{123}$ Moscow, Russian State Library, РГБ, 113.488, fol. 65-65v.

${ }^{124}$ Cf. Исповедание православной веры: Такожде вюрую и исповпдую ражаемаго безначялнп и присносущнть Сына// и Бога Слова от безначялнаго Бога и Отия, благоволениемг Отчимъ и оспнениемг Святаго Духа зачята бывша въ пречистых ложеснах Пресвятыа и приснодевы Марии Божиа матери [...] Еще к симъ исповпдую и про//повпдую себю же и всякому благовпрному преблагословеную владычииу мою Богородииу, прпдстателнииу и заступнииу вспмм правоставным християном, по всему быти святую и пречистую и пренепо рочную и Приснодеву (ПРеП. МАКСИМ Грек II, p. 52, 53).
} 
Thus, this prayer suggests that it could be a song - it contains prominent, repeated expressive verses that could be chanted and act as a refrain in this rhythmical prose:

Inspire me, Empress [Queen], with the power of the words and give me a stronghold of pre-images, to feel the divine entities with compassion of the heart ${ }^{125}$.

The latter expression could be theologically explained by means of a biblical exegesis, in that the holiness of the Mother of God was also foretold in certain verses of the Psalms as well as in certain pre-Christian oracles as proto-forms of the unshakable faith in the Son of God; there, the oral Christian tradition of the pronouncement of the "future" biblical reality was shown. The latter texts were known to Maximus, who also translated two short poems attributed to the Sibyllian tradition, with an Acrostic to Jesus Christ ${ }^{126}$.

Maximus the Greek wrote many heterogeneous texts, titled prayers, which reflected his theologically polemical or liturgical stance on Orthodox contemplation. The conclusion of most of them is the appeal to include Mary in each thanksgiving Trinitarian prayer (The Ode to the Holy Trinity, The Prayer to All-pure Mother of God, and also About the Lord's Sufferings, The Prayer of Mother of God, The Prayer of Mary of Egypt ${ }^{127}$, The Prayer of Susanna, The Song about How St. Peter Cried $\left.\mathrm{Out}^{128}\right)$. In the prayer About the Birth of God the Son, Maximus wrote critically against the Jews, while in the three texts entitled The Third Poem of the Prophetess Anna (i.e. the third liturgical song after the reading of the 150 psalms $^{129}$ ), he argued against astrological beliefs - one of his main polemical subjects. The Prayer of Mary of Egypt confirms the tripartite structure of Maximus's prayers: the personal repentance is followed by the thanksgiving prayer to the Mother of $\operatorname{God}^{130}$, and the final metamorphose of the mortal dark of the human flesh disappears on account of the pain of the discovery of spiritual enlightening (often paraphrasing the evangelical scene of the brightness at the attendance of the Holy marriage, stemming from Matthew 20,1-16). Moreover, bearing in mind that Maximus the Greek was barred from receiving the Communion for more than 21 years, it seems reasonable to conclude that he was forced to create his own prayers for a personal

\footnotetext{
${ }^{125}$ Moscow, Russian State Library, РГБ, 113.488, fol. 70 r.

${ }^{126}$ Moscow, Russian State Library, РГБ, 256.264, f. 64 v. -66 v.

${ }^{127}$ Moscow, Russian State Library, РГБ, 256.264, f. 66 v. -67 v., 220 r. -222 v.

${ }^{128}$ Cf. a similar canticle of St. Ambrose of Milan, "Super Luc. de poenit., distinct", P. Trubar, Articuli oli deili te prave stare vere kersanske, Tübingen 1562, p. 143.

${ }^{129}$ Only in the manuscript: Moscow, Russian State Library, РГБ, 256.264. The three texts are followed by a text introducing a special veneration of the Eucharistic bread (Holy Communion) and the veneration of the Mother of God (Gr. Пava jia), while pointing out the mistaken beliefs of astrological thinking.

${ }^{130}$ It is different from the traditional prayers treating the legend of St. Mary of Egypt, also recognized in the iconographic tradition, cf. А.Ю. НикифоровА, Из истории..., p. 181-182.
} 
liturgy ${ }^{131}$. This is why his prayers, dedicated to the three entities of the Holy Trinity as well as to the Mother of God, can be understood as basic monastic prayers - not only acting as Maximus's preamble to a text, but also his substitutes for the standard liturgical prayers.

\section{Epilogue}

The most important item in Maximus the Greek's approach to the Holy Trinity was his theologically personal attitude to the Holy Theotokos, which led to the kernel of his theological system, with its specifically synthetic theological-liturgical-iconographical understanding of the Christian tradition ${ }^{132}$. Maximus's synthetic theological vision is evident in his Canon to the Holy Spirit Paraclete ${ }^{133}$ which he wrote during his first imprisonment in the dark cell of the Joseph Volokolamsk Monastery, on a wall, with a piece of wood charcoal. This piece displays certain traits of a confessing prayer, especially in that it includes a personally addressed speech

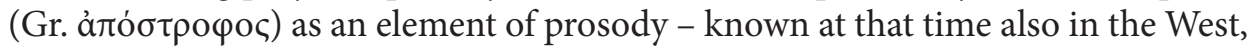
but equally present in the oldest pieces of Slavic hymnography ${ }^{134}$, where certain elements were also translated from Latin and not only from Greek. The meaning of this poetic prayer, which could offer a pious end of the mortal lifetime, also conveyed an invocatory moment with empowered eschatological mindfulness in the personal prayer for the beginning of Maximus's daily writing. It is to be sung at the third hour of the day (i.e. very early in the morning) - as the author notes in the overture ${ }^{135}$ - and it is supposed to be a personal, precatory, solicitous prayer (“покаянный канон”). It could be presumed that Maximus pronounced this prayer silently, but in extenso: not only as a prelude, as is common in the present days $^{136}$, but as his inner Kanon Parakletikos, a supplicatory hymn forming a part of his daily compline.

After the dedication to the Holy Spirit and the introduction of the Canon, Maximus contemplates the interior of the Temple or Church (Радуйся дверь Господня непроходимая - Rejoice, the Lord's door that could not be entered $)^{137}$ in the form

${ }^{131}$ Cf. С. Белокуров, О библиотеке..., p. LXXX-LXXXII.

${ }^{132}$ Cf. Sankt Petersburg, Russian National Library, РНБ, Сoф. 1498, f. 119 v., 121 v.

${ }^{133}$ We are dealing with $16^{\text {th }}$-century manuscripts: Moscow, Russian State Library, РГБ, 247.302, f. 423 r.- 440 r.; РГБ, 173.I.42, f. 408 v.-416 r.; РГБ, 304.I.267, f. 176-187 v.

134 Т.И. АФАНАСьЕВА, М.Г. ШАРИХИНА, Употребление перфекта 2-го лица ед. числа вместо аориста: к вопросу о времени становления грамматической нормы, ДРВМ 67, 2017, p. 103. On how important this kind of addressing was to Maximus see more in: И.В. Вернер, Грамматическая..., p. 116; especially regarding addressing God the Son, N. ZaJC, Some Notes..., Part 2, p. 380-381.

${ }^{135}$ Moscow, Russian State Library, РГБ, 247.302, f. 423 r.-440 r.; РГБ, 173.I.42, f. 409-416; РГБ, 304.I.267, f. 176-187 v.

${ }^{136}$ Cf. H.J.W. Tillyard, Byzantine..., p. 12.

${ }^{137}$ Moscow, Russian State Library, РГБ, 247.302, f. 423 v.; РГБ, 173.I.42, f. 409 r.; РГБ, 304.I.267, there are added the following words, clearly addressing the Mother of God: Joy the walls and Intercession// 
of an authentic diataxis, known from a $16^{\text {th }}$ century ${ }^{138}$ prayer of Vatopaidi, in fact an implicit address to the Mother of God of a $13^{\text {th }}$-century icon called Paramythia. At the same time, this form corresponds to the prayer-invitation of the icon of the Holy Theotokos of Iviron ${ }^{139}$, called the "Doorkeeper". This kind of reference (ref. Ez 43, 27; 44, 1-4) not only fulfilled the liturgical rule of worshiping the icon before leaving the church, when the igumen would always give the keys of monastery's doors to the doorkeeper, but also served to dedicate the Church. Additionally, it is repeated literally in the bilingual Greek-Slavic Kontakion to the Annunciation, which Maximus wrote down in his Greek Psalter in 1540 when teaching Greek to the monk Benjamin ${ }^{140}$. This Kontakion, which Maximus entitled the New Kontakion to the Annunciation ${ }^{141}$, was traditionally inserted in the last hymn of the Akathistos prayer ${ }^{142}$. The issue can be observed iconographically in the scenes of the Holy Annunciation (from the second half of the $11^{\text {th }}$ century) and the Deisis (from the late $11^{\text {th }}$ - early $12^{\text {th }}$ century) in the mosaics of the Vatopaidi Monastery; it was also proclaimed by Andronicus II in a chrysobull (1301 $\left.{ }^{143}\right)$, a copy of which Maximus carried from Athos to Moscow in $1518^{144}$. Indeed, it was during the time of Andronicus II - who had an important part in confirming Stephen the Great as the Tsar and carrying out the 1296 jurisdictional reform ${ }^{145}$ - that the honouring of the Holy Theotokos at Vatopaidi was expanded.

The above-described liturgical moment and dedicatory gesture of opening the doors followed the anaphora before the receiving the Holy Communion ${ }^{146}$. Similarly, Igor' Ševčenko found anonymous verses in the margins of the Milan

the Protection to whom we are running to, Joy//the windless harbour, that had never//experienced the marriage, You who gave a birth and the body//to the Creator and Your God,//I beg You, please, us, who are praying, do not//neglect, and we are praising and knee//ling before your Birth (f. $176 \mathrm{v}$.).

${ }^{138}$ Н.Д. УСпенский, Византийская литургия: историко-литургическое исследование. Анабора: опыт историко-литургического анализа, Москва 2006, р. 212.

${ }^{139}$ Maximus the Greek's text about the Vatopaidi Icon of the Mother of God is preserved in Moscow, State Historical Museum, ГИМ, Хлуд. 34, f. 236v.-240r. A copy of this icon was brought to Russia in the $17^{\text {th }}$ century at the request of the Patriarch Nikon.

${ }^{140}$ ПреП. МАКСИм Грек II, p. 14.

${ }^{141}$ Sankt Petersburg, Russian National Library, РНБ, Соф. 78, f. 160 v.

${ }_{142} \mathrm{~T}$. Velmans, Une illustration inédite de l'acathiste et l'iconographie des hymnes liturgiques a Byzance, CAr 22, 1972, p. 133.

${ }^{143}$ Le Mont Athos et l'Empire byzantine - Tresors de la Sainte Montagne, Paris 2009, p. 136, an. 45.

${ }^{144}$ С.М. КАштАнов, К истории русско-греческих культурных связей в XVI в., [in:] Московия. Проблемы византийской и новогреческой филологии, Москва 2001, p. 214; Н.В. СиницынА, Послание Максима Грека Василию ІІІ об устройстве афонских монастырей (1518-1519 гz.), ВВ 26, 1965, p. 113.

145 Д.И. Мурешан, Om второго..., p. 131-132; Р. LemerLe, Le Juge général des Grecs et la réforme judiciaire d'Andronic III, [in:] Mémorial Louis Petit. Mélanges d'histoire et d'archéologie byzantines, Bucarest 1948 [= AOC, 1], p. 292-316.

${ }^{146}$ R.F. TAfT, A History of the Liturgy of St. John Chrysostom, vol. V, The Precommunion Rites, Roma 2000 [= OCA, 261], p. $70-72$. 
manuscript that contains many of Maximus's poems, corresponding to his favourite meditation about the decoration of the church (which might be identified with the Church of the Theotokos Pammakaristos) ${ }^{147}$, expressed in several of his writings. The latter could confirm that the verse - used by Maximis in the function of a Katavasia - must be sung in the body of Church ${ }^{148}$. The echo of the antiphons of the enarxis and of the hymns of the Little Entrance could be heard ${ }^{149}$. The subtle allusion that the portal of the church or monastery is the gate of heaven is but a humble overture to the prayer service (the "Moleben"), as the Canon to the Holy Spirit Paraclete by Maximus the Greek is titled. After Psalm 50, the heirmos and the troparia the author implies the special rule of the further chanting glorification. In particular, he notes the combination of a specific ${ }^{150}$ sequence, indicating the three praying songs of praise, variating and metamorphosing through the whole Canon until the end. This rule is presented in the Prologue to the First Ode as the three versions of the Kyrileison (to God the Son, Jesus Christ; to the Holy Trinity; to the Holy Paraclete) and it is observed after every heirmos at the beginning of each ode. In other words, Maximus added to each song an obligatory praise of the Holy Theotokos as two special "thanksgiving" verses ("Dоха" - "Слава") in honour of the Virgin Mary, which should form the conclusion of every song ${ }^{151}$. A verse or two verses in honour of the Virgin Mary are regularly inserted between the odes; thus, every ode also begins with the initial words of the heirmoi, similar to those that were later known as the heirmoi of the Kanon Parakletikos to the Holy Theotokos (as the $9^{\text {th }}$ part of the Greek liturgical Anthologion ${ }^{152}$ ). Maximus the Greek's Canon to the Holy Paraclete with 9 odes (traditional for the Canon ${ }^{153}$ ),

\footnotetext{
${ }^{147}$ The anonymous verses in the Milan manuscript, once attributed to Mikhail Trivolis (I. ŠEvČENKo, The Four..., p. 298-299), describe the Church of the Theotokos Pammakaristos, previously of the Patriarchate of Constantinople (whereas the verses mention Patriarch Pachomios, dating them between 1505 and 1514, N.P. ŠEvčEnko, The Service of the Virgins's Lament Revisited, [in:] The Cult of the Mother of God in Byzantium. Texts and Images, ed. L. Brubaker, M.B. Cunningham, Farnham 2011 [= BBOS], p. 298-299. Note also that the same time as the daughter of Stephen the Great, Elena, married Ivan III, Stephen bought for his son Alexander the "residence of Moldavian princes", only a few metres from the Imperial Church of Pammakaristos. Neagoe Basarab helped restore this church, Д.И. МурешАН, От второго..., p. 117, 138.

${ }^{148}$ Hymns of the Eastern Church, trans. et ed. J.M. Neale, ${ }^{2}$ London 1863, p. 845.

${ }^{149}$ In 1509, the first such Prologion was printed in Venice, F.E. Brightman, Introduction, [in:] Liturgies Eastern and Western, ed. IDEM, Oxford 1896, p. LXXXII.

${ }^{150}$ This opinion was expressed by a Russian scholar, Г.А. КАзимовА, Канон молебен к божественному и поклоняемому Параклиту преподобного Максима Грека: к вопросу об атрибуиии и функциональной трансформации текста, [in:] Лингвистическое источниковедение и история русского языка (2004-2005), Москва 2006, р. 290.

${ }^{151}$ Cf. H.J.W. Tillyard, Byzantine..., p. 19.

${ }^{152}$ S. SAlaville, Liturgies orientales, Paris 1932 [= BCSR, 87bis], p. 193. The canon to the Holy Theotokos was first attributed to the Metropolitan of Crete, Elias II (1111-1120), who titled in this manner the service for the rite of the Proskomedia, V. LAUREnT, Le rituel de la proscomidie et le métropolite de Crète Élie, REB 16, 1958, p. 122.

${ }^{153}$ E. Wellesz, The "Akathistos". A Study in Byzantine Hymnography, DOP 9/10, 1956, p. 200-202.
} 
containing approximately 45 songs of special eulogy with interchangeable dedications to God the Son, to the Holy Trinity and to the Holy Spirit, as well as to the Holy Mother of God, also reflects the basic principles of the Akathistos hymn and the main liturgical canticles (eight from the Old Testament and one from the New Testament, i.e. the Magnificat $)^{154}$. The First Ode is an implicit praise to the incarnation of the Logos, wholly present on earth, which expresses the Orthodox view against Apollinarius of Laodicea (a heretical teaching on the unleavened Eucharist), but at the same time the final call includes a praise of the Mother of God represented as Holy Earth ${ }^{155}$. The Second Ode is in fact missing, according to the earliest editions ${ }^{156}$; the Third ${ }^{157}$ as well as the Fifth Odes are - after mentioning the Holy Trinity briefly - dedicated to an extended invocation of the Holy Spirit, subsequently turning into a short prayer to the Holy Theotokos ${ }^{158}$. However, Maximus's Canon to the Holy Paraclete does not feature concrete imitations of the forms of the Great Canon (the "Lenten Canon" by Andrew of Crete). The Fourth Ode, after addressing the Lord shortly, expresses gratitude to the Holy Trinity and conveys a warm orison to the Holy Mother of God. In the Sixth Ode, the "specific sequence" of addressing is strictly adhered to, following the order of God the Son, the Holy Trinity, the Holy Paraclete, and the Holy Theotokos:

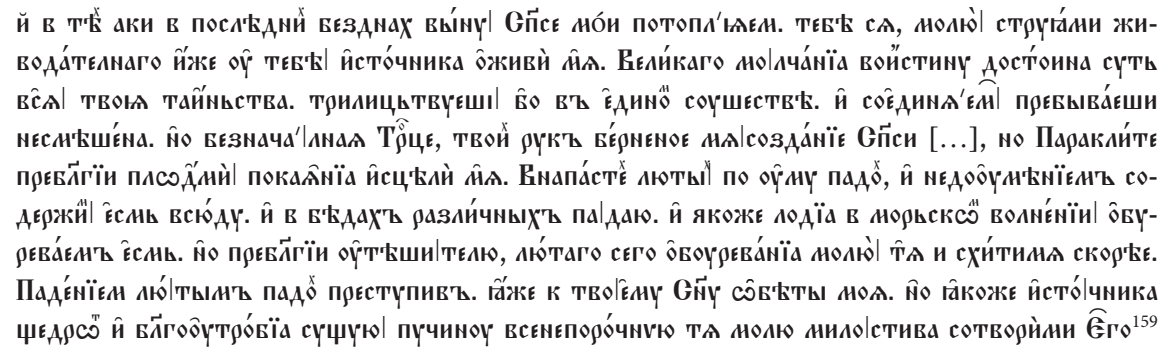

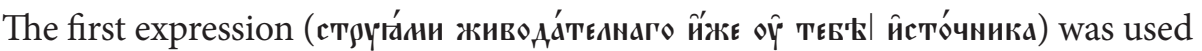
by Maximus already when he was a Vatopaidian monk, in the Canon to St. John

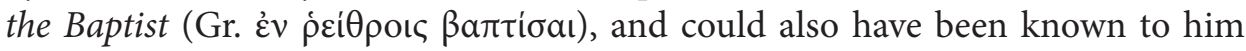

\footnotetext{
${ }^{154}$ The connections among the Odes of the Canon and the Canticles were known from the Canons of John of Damascus, particularly from his Canon for the first Sunday after Easter, E. WeLlesz, The History..., p. 222.

${ }^{155}$ IDEM, The "Akathistos"..., p. 147.

${ }^{156}$ P.F. Krypiakiewicz, De hymni Acathisti auctore, BZ 18, 1909, p. 361.

${ }^{157}$ Cf. A. Kretski, Véliki kánon, Ljubljana 2013, p. 59, 69; Великий покаянный канон. Творение святого Андрея Критского. С прибавлением Жития преподобной Марии Египетской, Москва 2013, p. 124-125.

${ }^{158}$ Cf. A. Kretski, Véliki..., p. 105.

${ }^{159}$ Moscow, Russian State Library, РГБ, 247.302, f. 435 v.-436 r.; РГБ, 173.I.42, f. 411 v.-412 r.; РГБ, 304.I.267, f. 181 r. -182 v.
} 
from the homilies of Gregory of Nazianzus; it served to denote the spiritual inspiration shown in literary eloquence ${ }^{160}$. This Ode also features the semantic content of a specific metaphor - a literary depiction of the condition of the human soul

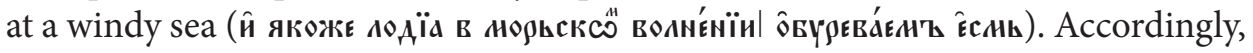
the image of a calm harbour ${ }^{161}$ - which appeared already in the Canon to St. John the Baptist ${ }^{162}$, as well in the beginning of the present Canon ${ }^{163}$ and at its very end, with the direct naming of the Theotokos as a such peaceful place for believers

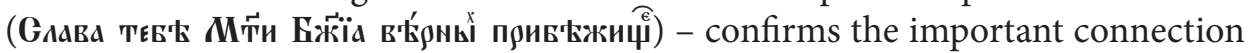
with Maximus's earlier poetic and prayer activity. In between, after the addressing of the Holy Trinity, we find the acknowledgment that the Holy Spirit proceeds only from the Father; thus, we could propose that Maximus the Greek wrote his Canon to the Holy Paraclete as a result of his humble prayer and concentration on the moment of epiklesis (the basis of his battle against the filioque) in a non-eucharistic context $^{164}$. In this way, the presence of the Divine Spirit in Maximus's Canon is an invocatory sign of the permission for addressing the Lord, and the spread of the fearful but free creativity of the individual:

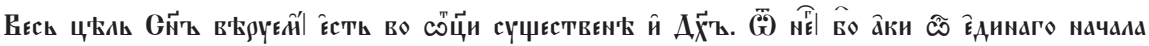

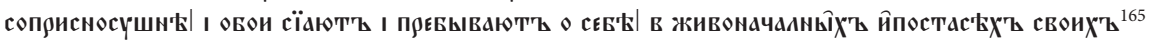

Before the final prayer to the Holy Spirit in the form of an epilogue, there is a paraphrase of the Athonite icon "Aksion Estin" - which was also the quintessence of Maximus's Canon to St. John the Baptist - assimilated to the veneration of the Holy Paraclete.

However, Maximus's monastic, humble attitude was very precise: his aim was to balance the veneration among the voices of the Orthodox Trinity ${ }^{166}$. Traditionally,

\footnotetext{
${ }^{160}$ A Patristic Greek Lexicon, ed. G.W.H. LAmpe, Oxford-London 2010, p. 1213.

${ }^{161}$ Cf. Maximus's description of Manuzio’s printing symbol, depicting an anchor. Maximus gave his own interpretation of the anchor, according to which it represents - like a printed manuscript - the salvage for the ship at a windy sea; similarly, Manuzio's wise innovation, which could fix the human "manuscript", is a metaphor of a firm localization ("a calm, safe harbour") for a solemn soul, N. ZAJC, Some Notes on the Life and Works of Maxim the Greek (Michael Trivolis, ca 1470 - Maksim Grek, 1555/1556). Part 1: Biography, Scri 11, 2015, p. 319.

${ }^{162}$ The Holy Mount Athos, The Holy Monastery of Vatopaidi, Cod. 1016, f. 32 v.

${ }^{163}$ See footnote 137; cf. "the windless harbour".

${ }^{164}$ Cf. M.E. Johnson, The Origins of the Anaphoral Use of the Sanctus and Epiclesis Revisited. The Contribution of Gabriele Winkler and Its Implications, [in:] Crossroad of Cultures. Studies in Liturgy and Patristics in Honor of Gabriele Winkler, ed. H.-J. Feulner, E. Velkovska, R. TAFt, Roma 2000, p. 405-442 [= OCA, 260], p. 408.

${ }^{165}$ Moscow, Russian State Library, РГБ, 247.302, f. 435 v.-436 r.; РГБ, 171.I.42, f. 412 r.; РГБ, 304.I.267, f. $181 \mathrm{r}$.

166 Thus, it is worth adding that many linguistic specifics regarding Maximus's veneration of the Holy Theotokos (for example, in the list of analogue Greek and Old Church Slavic expressions for the
} 
the Kanon Parakletikos was always addressed to the Virgin, especially in Constantinople, and it was also associated with the funerary Canon ${ }^{167}$. The praise of the Mother of God forms the conclusion of each ode of Maximus's Canon and also of each of his Trinitarian venerations. The author dedicated this hymn to the Holy Paraclete (the Canon ends in a prayer to the Holy Spirit). Through the appropriate Trinitarian addressing in direct speech, with echoes from the ancient Kontakia, dating to the times before the $7^{\text {th }}$-century Byzantine reform and its expansion ${ }^{168}$, in his Canon to the Holy Spirit Paraclete ${ }^{169}$ Maximus perfects the Slavic rhythmical variations and theological proclamations that yield poetic correspondences to the oldest prayers and Byzantine hymns. While managing to find an equal place for the Holy Theotokos alongside the three entities of the Orthodox Trinity in his theological writings (as shown above), he at the same time reaffirms the pious veneration of the Holy Mother of God that began to flourish especially from the $11^{\text {th }}$ to the $15^{\text {th }}$ century in Byzantine hymnography, but at the same time also in Western as well as Slavic liturgical poetry ${ }^{170}$. We may note that Maximus's contribution offers praise and thanksgiving to the Holy Mother of God with the power of vigil singing during the whole night without a pause, as was primary in the Akathistos, when no signs of involving the Holy Theotokos in military service were yet to be seen ${ }^{171}$. Thus, it is also obvious that Maximus the Greek was aware that prayers to the Holy Mother of God had the power of preventing the various heresies and dubious teachings; he expresses this thought in his Prayer to the Holy Mother of God, and also about the Lord's Suffering ${ }^{172}$, just as it was expressed in the tradition of the Akathistos hymns, especially concerning the argumentation of the Christological $\operatorname{dogma}{ }^{173}$. In this way, he was able to reach back into cultural memory and reveal the devoted creativity of the first Slavic liturgical poet, Constantine the Philosopher $^{174}$ : the latter author wrote a similar accordance in the Canon, entitled To the Memory of Saint Demetrius and Martyr in Christ ${ }^{175}$ and including the Holy Virgin in the Trinitarian form. Hence, already his vision was compared to the writings

Holy Theotokos, among them the very significant expression literally denoting a lily (Gr. kriin) that Maximus wrote about) are preserved in the manuscript inserted in the Serbian Prayer and Liturgical Service Book, first printed in Venice in 1546, cf. Ljubljana, National Library, K 19996.

${ }^{167}$ N.P. ŠEvčEnKo, The Service..., p. 252.

${ }^{168}$ E. Wellesz, The "Akathistos"..., p. 203.

${ }^{169}$ Unfortunately, a detailed study of this prayer-poem remains a task for the future.

${ }^{170}$ Cf. Florence, Biblioteca Laurenziana, San Marco 32; G. Ropa, Il culto della Vergine a Bologna nel Medioevo, [in:] Codex Angelicus 123. Studi sul graduale-tropario bolognese del secolo 11. e sui manoscritti collegati, ed. M.T.R. Barezzani, G. Ropa, Cremona 1996, p. 28-32.

${ }^{171}$ E. Wellesz, The "Akathistos"..., p. 151-152.

172 ПреП. МАКСИм Грек II, p. 60-61.

${ }^{173}$ E. Wellesz, The "Akathistos"..., p. 147-148.

${ }^{174}$ Cf. I. ŠEvČEnKo, On the Greek..., p. 52.

${ }^{175}$ R. Jаковson, Selected Writings, vol. VI, Early Slavic Paths and Crossroads, pars 1, ed. S. Rudy, Berlin-New-York-Amsterdam 1985, p. 304-306. 
of Gregory of Nyssa, who devoted the first of his sermons to the "mystery of the Canticles" ${ }^{\prime 176}$. Indeed, Maximus the Greek polished the Church Slavic liturgical language to such a level that it could serve him as a voice analogous and parallel to the Greek language of the Gospels, focusing on the service to the Christian God in the Holy Trinity.

It had been proposed that Maximus the Greek precisely remembered the exact formal characteristics of the ancient Christian texts in Greek, as well as the Church Slavic usage of the biblical language ${ }^{177}$. In the present study, it is proposed that at the moment of his arrival in Moscow on March $5^{\text {th }}, 1518$, Maximus had in his memory the sound of the spoken South Slavic languages, which was reflected in his use of Slavic in his manuscripts; at the same time, he had a visual memory of the Slavic manuscripts from the Athonite libraries, mainly of Serbian ones with liturgical content ${ }^{178}$ (this corresponded to the final stage of the South Slavic influence, in which the Bulgarian elements were no longer authoritative in Russia ${ }^{179}$ ). But Maximus had not been in contact with Russian manuscripts before his arrival in Moscow (this is confirmed in the short manuscript where he describes the monasteries of the Holy Mount Athos, not listing the Russian one among them) ${ }^{180}$. In particular, his personal variety of Slavic - especially in its lexical and phonetic aspect ${ }^{181}$ - shows that he had an excellent acoustic linguistic memory ${ }^{182}$. This helped him grasp two forms of Slavic languages: one from the Western South Slavic nations (Slovenian or Croatian - possibly members of the Glagolitic community - from the Venetian and Istrian lands), and the other from the South Macedonian milieu. Besides, he had contact with Albanian in Sicily (the Basilian communities) ${ }^{183}$, where he also travelled during his Italian period according to his manuscripts. All of these areas had highly bilingual and multi-ethnical, although Christian populations. The above-mentioned languages were characterized by a significant number of sophisticated, non-simplified grammatical categories, including some idiosyncratic and synthetic archaic forms ${ }^{184}$; all of this became quite representative for

\footnotetext{
${ }^{176}$ Ibidem, p. 325.

177 See H.M. Olmsted, Recognizing Maksim Grek: Features of His Language, Psl 10, 2002, p. 7-14.

${ }_{178}$ B.А. Мошин, О периодизации..., p. 85.

${ }^{179}$ Ibidem, p. 96-97.

${ }^{180}$ Moscow, Russian State Library, РГБ, 256.264, f. 133 v.-134 r.

${ }^{181} \mathrm{Cf}$. our current research, based on the linguistic analysis of the language of the early manuscripts of Maximus the Greek.

${ }^{182}$ Maximus attested that he had a very good memory of the verbal constructions of Ancient (Hellenistic) Greek literature, although he had not read for many years, В.Ф. РжигА, Неизданные сочинения Максима Грека, Bsl 6, 1935-1936, р. 88.

${ }^{183}$ F.E. BRIGHTMAN, Introduction..., p. XC-XCI.

${ }^{184}$ Cf. A.N. Sobolev, Hybrid..., p. 1253.
} 
Maximus's personal Slavic idiom. At the second stage of the translation process, his texts reflect the careful study of each single word or expression, but with special attention to the rhythmical order; the original wording in Greek is closely adhered to (so-called sublexical morphemic translational correspondences). Thus, Maximus paid significant attention to the stress of words that could be accented the same way as in Greek, which was dominant for the accentuation in spoken Russian (especially in monastic communities and at the court) in the $16^{\text {th }}$ century. It has been noticed that the accentuation of some words - especially those that had three stresses in his prayers - reflect the accentual differences of the Western South Slavic dialects (Slovenian and Čakavian), while no such distinctions existed in Russian $^{185}$. Not surprisingly, Maximus accepted that kind of textual treatment in the process of his own writing as well. This might provide the explanation for why not a single text that Maximus wrote in Slavic has been preserved. He would dictate his works, and therefore, at the following stage, also correct them by clarifying the meaning of each single theologically decisive word. As a result, he managed to create his own variety of Slavic, with the aim of praying properly and in accordance with the Greek Orthodox theology.

This kind of linguistic reception of translated words significantly intensified the condensed stylistic manner and the periodically rhythmical effects of his texts - which, of course, reflected poetic prose. He made prominent use of constructions based on anapaest accentuation and assonant metrical patterns (both also known from biblical canticles ${ }^{186}$ ), combined with the caesura ending of the theological denotation of the thought. Such a principle was used in Old Byzantine patristic alphabetic hymns as well as in Slavic pieces of similar content; Maximus the Greek's lexical selection patterns had much in common with these works. Indeed, Maximus's poem written in Slavic entitled Verses on Repentance shows a basic Byzantine rhythmical organization of the metrical unit of the colon, or verses in which the number of syllables may vary from one to fifteen or sixteen in each colon ${ }^{187}$. This may occasionally fall into a line, composed of twelve syllables, with caesura (division, or diaeresis) after the fifth or the seventh syllable ${ }^{188}$; this was typical of Church Slavic prayers ${ }^{189}$, and especially perceivable in Maximus's

${ }^{185}$ A.F. Gove, The Slavic Akathistos Hymn. Poetic Elements of the Byzantine Text and Its Old Church Slavonic Translation, München 1988 [= SBe, 224], p. 93, an. 18.

${ }^{186}$ U. Chevalier, Poésie..., p. 13.

${ }^{187}$ Cf. H.J.W. Tillyard, Byzantine..., p. 40. This division of his diction was not respected in the critical edition of his works, Преп. Максим Грек II, p. 199-206.

${ }^{188}$ R. NAHTigal, Rekonstrukcija treh starocerkvenoslovanskih izvirnih pesnitev, Ljubljana 1942, p. 51. Maximus the Greek's speech shows a somewhat wider use of the descend of the theological thought after the seventh syllable (note that such "septénaire" rhytmical devision was characteristic of Greek melodic liturgical songs, but not for Latin - U. Chevalier, Poésie..., p. 9).

${ }^{189}$ Cf. V. VAliavitcharska, Rhetoric..., p. 145. 
prayers $^{190}$. In such a theological and poetic manner, through the personal practice of the inner prayer, Maximus the Greek managed to recreate in the Church Slavic language an equivalent of the oldest patterns of Christian liturgy, as could be found in Greek liturgical manuscripts from the $9^{\text {th }}$ century onwards. His personal language reflected his awareness of Byzantine hymnographical rules as well the Church Slavic models of prayer-related apprehension and linguistic contemplation.

Thus, Maximus the Greek raised the Church Slavic liturgical language to a level at which it could serve him as a voice analogous and parallel to the Greek of the Gospels, focusing on the prayerfulness to God in the Holy Trinity. The theological writings of Maximus the Greek were significantly marked not only with his firm knowledge (memory) of the Holy Scripture and the Fathers of the Orthodox Church (Gregory of Nazianzus, Gregory of Nyssa, Maximus the Confessor), but also with a significant poetic effect. This is the reason for which the late Byzantine (Constantinopolitan) and Athonite liturgical traditions could be understood as the most important sources of Maximus's spiritual inspiration. However, it could not be said that the above-mentioned sources were directly reproduced or literally translated by Maximus into the Slavic language. On the contrary, his prayers are thoroughly theological and contain a proper appreciation of Mary's place in the biblically formed scheme of the human redemption, as long as She is seen in union with Jesus Christ. By implicitly - though constantly - underlining the holiness of the Mother of God, Maximus the Greek combined the iconographical, hagiographical and liturgical sources of Christian knowledge, which completed his Orthodox theological system with a significant harmonic argumentation, marked with a profoundly humane pathos. But only the detailed study of the deeply personal language of his Slavic idiolect - i.e. the language of his theological works and his individual, occasionally hermetic prayers - could give us insight into the traces of his personal prayer practice, as well as the inner prayer practice of the Holy Vatopaidi Monastery.

\footnotetext{
${ }^{190}$ Indeed, Maximus the Greek was extremely cautious about stress marks: in particular, he renounced the use of the "varia" in the middle of the word and used the combination of the "varia" and the "kamora", В.В. Колесов, Надстрочные знаки «силь»» в русской орфографической традиции, [in:] Восточнославянские языки. Источники для их изучения, еd. Л.П. ЖуковскАя, Н.И. ТАРАБАСОвА, Москва 1972, p. 231, 253. He was thus able to note precisely the stressing point

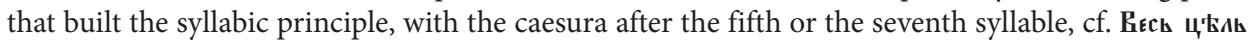

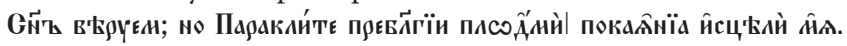




\section{Bibliography}

\section{Manuscripts}

Florence, Biblioteca Laurenziana, San Marco 32.

The Holy Mount Athos, The Holy Monastery of Vatopaidi, Cod. 1016.

The Holy Mount Athos, The Holy Monastery of Vatopaidi, Cod. 1134.

Milan, Biblioteca Ambrosiana, Id. 2002.

Moscow, Russian State Library, РГБ, 113.488.

Moscow, Russian State Library, РГБ, 113.544.

Moscow, Russian State Library, РГБ, 173.I.42.

Moscow, Russian State Library, РГБ, 247.302.

Moscow, Russian State Library, РГБ, 256.264.

Moscow, Russian State Library, РГБ, 304.I.267.

Moscow, State Historical Museum, ГИМ, Муз. 3475.

Moscow, State Historical Museum, ГИМ, Син. 791.

Moscow, State Historical Museum, ГИМ, Увар. 15/85.

Moscow, State Historical Museum, ГИМ, Хлуд. 34.

Moscow, State Historical Museum, ГИМ, Щук. 4.

Paris, Bibliothèque nationale (BN), Gr. 1994.

Paris, Bibliothèque nationale (BN), Slav. 123.

Sankt Petersburg, Russian National Library, РНБ, Сoф. 1498.

Sankt Petersburg, Russian National Library, РНБ, Сoф. 78.

Vatican, Biblioteca Apostolica Vaticana, Barb.gr. 100.

Vatican, Biblioteca Apostolica Vaticana, Reg.gr. 83.

\section{Primary Sources}

Apanta Agiou Maximou Graikou, vol. IV, Logoi, Agion Oros 2017.

Herberstein S., The Gratae Posteritati (Edition Stored in Ptuj, 1560), Ljubljana 2017.

Humanist Educational Treatises, trans. C.W. Kallendorf, Cambridge Massachusetts-London 2008 [= The I Tatti Renaissance Library].

Hymns of the Eastern Church, trans. et ed. J.M. NeALE, ${ }^{2}$ London 1863.

Kretski ANdrej, Véliki kánon, Ljubljana 2013.

Maximus the Confessor, The Life of the Virgin, trans. et ed. S.J. Shoemaker, New Haven-London 2012.

Menologii anonymi Byzantini saeculi X quae supersunt. Fasciculos duos sumptibus Caesareae Academiae Scientiarum e Codice Mosquensi 376 Vlad, ed. V.V. LATYšEv, Leipzig 1970 [= Subsidia Byzantina lucis ope iterata, 12].

Prepodobny Maksim Grek, Sočinenija, vol. I-II, Moskva 2008-2014.

Sudnye spiski Maksima Greka i Isaka Sobaki, ed. N.N. PokrovsкiJ, Moskva 1971.

Velikij pokajannyj kanon. Tvorenie svjatogo Andreja Kritskogo. S pribavleniem Žitija prepodobnoj Marii Egipetskoj, Moskva 2013. 


\section{Secondary Literature}

Afanas'eva T.I., ŠARIChIna M.G., Upotreblenie perfekta 2-go lica ed. čisla vmesto aorista: $k$ voprosu o vremeni stanovlenija grammatičeskoj normy, “Древняя Русь. Вопросы медиевистики” / “Drevnjaja Rus'. Voprosy medievistiki” 67, 2017, p. 102-109.

Belokurov S., O biblioteke moskovskich gosudarej v XVI stoletii, Moskva 1899.

Bornert R., Les commentaires byzantins de la divine liturgie. Du VII au XVe siècle, Paris 1966 [= Archives de l'Orient chrétien, 9].

Brightman F.E., Introduction, [in:] Liturgies Eastern and Western, ed. F.E. Brightman, Oxford 1896, p. XVII-CI.

Chevalier U., Poésie liturgique du Moyen Âge, Paris-Lyon 1893.

ČIžEvskij D., History of Russian Literature. From the Eleventh Century to the End of the Baroque, S-Gravenhage 1960.

Denissoff É., Maxime le Grec et l'Occident, Paris-Louvain 1943.

Fonkič B.L., Novyj avtograf Maksima Greka, [in:] B.L. Fonkič, Grečeskie rukopisi i dokumenty $v$ Rossii v XIV - načale XVIII v., Moskva 2003 [= Россия и христианский Восток. Библиотека / Rossija i christianskij Vostok. Biblioteka, 4], p. 74-79.

Garzaniti M., Michele Trivolis / Massimo il Greco (1470 - circa-1555/1556). Una moderna adesione al vangelo nella tradizione ortodossa, "Cristianesimo nella Storia" 36, 2015, p. 341-366.

Gorfunkel’ A.Ch., Milanskaja Psaltir’ Džovanni Krastone 1481 g. i gumanističeskaja kritika Biblii, [in:] Kollekcii. Knigi. Avtografy, 2, Knižnye redkosti Publičnoj biblioteki, Leningrad 1991, p. 29-43.

Gove A.F., The Slavic Akathistos Hymn. Poetic Elements of the Byzantine Text and Its Old Church Slavonic Translation, München 1988 [= Slavistische Beiträge, 224].

Havranek B., Aspects et temps du verbe en vieux slave, [in:] Mélanges de linguistique offerts à Charles Bally sous les auspices de la Faculté des lettres de l'Université de Genève par des collègues, des confrères, des disciples reconnaissants, Genève 1939, p. 223-230.

Ivanov A.I., Literaturnoe nasledie Maksima Greka. Charakteristiki, atribucii, bibliografija, Leningrad 1969.

JAGIČ I.V., Rassuždenija južnoslavjanskoj i russkoj stariny o cerkovnoslavjanskom jazyke, Sankt-Peterburg 1896.

Jakobson R., Selected Writings, vol. VI, Early Slavic Paths and Crossroads, pars 1, ed. S. Rudy, Berlin-New-York-Amsterdam 1985.

Johnson M.E., The Origins of the Anaphoral Use of the Sanctus and Epiclesis Revisited. The Contribution of Gabriele Winkler and Its Implications, [in:] Crossroad of Cultures. Studies in Liturgy and Patristics in Honor of Gabriele Winkler, ed. H.-J. Feulner, E. Velkovska, R. TAft, Roma 2000, p. 405-442 [= Orientalia Christiana Analecta, 260].

Kallistos W., The Final Mystery: the Dormition of the Holy Virgin in Orthodox Worship, [in:] Mary for Time and Eternity, ed. W.M. McLaughlin, J. Pinnock, Leominster 2007, p. 219-252.

Kaštanov S.M., K istorii russko-grečeskich kul'turnych svjazej v XVI v., [in:] Moskovija. Problemy vizantijskoj i novogrečeskoj filologii, Moskva 2001, p. 209-218.

Kazımova G.A., Kanon moleben k božestvennomu i poklanjaemomu Paraklitu prepodobnogo Maksima Greka: $k$ voprosu ob atribucii i funkcional' noj transformacii teksta, [in:] Lingvističeskoe istočnikovedenie i istorija russkogo jazyka (2004-2005), Moskva 2006, p. 281-294. 
Kolesov V.V., Nadstročnye znaki «sily» $v$ russkoj orfografičeskoj tradicii, [in:] Vostočnoslavjanskie jazyki. Istočniki dlja ich izučenija, ed. L.P. Žunovsкaja, N.I. Tarabasova, Moskva 1972, p. $228-258$.

Kravec E.V., Knižnaja sprava i perevody Maksima Greka kak opyt normalizacii cerkovnoslavjanskogo jazyka XVI veka, "Russian Linguistics" 15, 1991, p. 247-279.

Krypiakiewicz P.F., De hymni Acathisti auctore, "Byzantinische Zeitschrift” 18, 1909, p. 357-382.

Lash E., Biblical Interpretation in Worship, [in:] Orthodox Christian Theology, ed. M.B. Cunningham, E. Theokritoff, Cambridge 2008 [= Cambridge Companions to Religion], p. 35-49.

LAURent V., Le rituel de la proscomidie et le métropolite de Crète Élie, "Revue des études byzantines" 16,1958 , p. 116-142.

Layton E., Notes on Some Printers and Publishers of $16^{\text {th }}$ Century Modern Greek Books in Venice, "Thesaurismata" 18, 1981, p. 119-144.

Lemerle P., Le Juge général des Grecs et la réforme judiciaire d’Andronic III, [in:] Mémorial Louis Petit. Mélanges d'histoire et d'archéologie byzantines, Bucarest 1948 [= Archives de l'Orient chrétien, 1], p. 292-316.

Louth A., 'From Beginning to Beginning': Endless Spiritual Progress in St Gregory of Nyssa. Lecture at the XXI Conference on the Orthodox Spirituality, [in:] The Proceedings of the XXI International Ecumenical Conference on Orthodox spirituality "The Ages of the Spiritual Life", ed. E. BIAnchI, Bose 2014.

MaKarova A.L., Makedonskij ESSE-perfekt: Èvoljucija formy, [in:] Indoevropejskoe jazykoznanie $i$ klassičeskaja filologija-XXII (čtenija pamjati I.M. Tronskogo). Materialy Meždunarodnoj konferencii, prochodivšej 18-20 ijunja 2018 g., pars 2, ed. N.N. KaZAnsKiJ, Sankt-Peterburg 2018, p. 821-829.

Le Mont Athos et l'Empire byzantine - Tresors de la Sainte Montagne, Paris 2009.

Mošın V.A., O periodizacii russko-južnoslavjanskich literaturnych svjazej X-XV vv., [in:] Rus' i južnye slavjane. Sbornik statej k 100-letiju so dnja roždenija V.A. Mošina (1894-1987), ed. V.M. ZAGREBIN, Sankt-Peterburg 1998, p. 7-113.

Murešan D.I., Ot vtorogo k tret'emu Rimu (Rol' Patriarchata i rumynskich vlijanij), “Ориентиры...” 9, 2014, p. 116-153.

Nahtigal R., Rekonstrukcija treh starocerkvenoslovanskih izvirnih pesnitev, Ljubljana 1942.

Nikiforova A.Ju., Iz istorii Minei v Vizantii. Gimnografičeskie pamjatniki VIII-XII vv. iz sobranija monastyrja svjatoj Ekateriny na Sinae, Moskva 2012.

Olmsted H.M., Recognizing Maksim Grek: Features of His Language, "Palaeoslavica” 10, 2002, p. 1-26.

A Patristic Greek Lexicon, ed. G.W.H. Lampe, Oxford-London 2010.

Pitra J.-B., Des Canons et des collections canoniques de l'Église Grecque, Paris 1858.

Prochorov G.M., "Tak vossijajut pravedniki...”. Vizantijskaja literatura XIV v. v Drevnej Rusi, Sankt-Peterburg 2009.

Robins R.H., The Byzantine Grammarians. Their Place in History, Berlin-New York 1993.

Ropa G., Il culto della Vergine a Bologna nel Medioevo, [in:] Codex Angelicus 123. Studi sul graduale-tropario bolognese del secolo 11. e sui manoscritti collegati, ed. M.T.R. BAREZzANI, G. RopA, Cremona 1996, p. 3-33.

Runciman S., The Great Church in Captivity. A Study of the Patriarchate of Constantinople from the Eve of the Turkish Conquest to the Greek War of Independence, London 1968.

Runciman S., The Last Byzantine Renaissance, London 1970. 
Ržıga V.F., Kto perevel kratkuju povest' o vzjatii Konstantinopolja turkami, "Slavia" 13.1, 1934, p. $105-108$.

Ržiga V.F., Neizdannye sočinenija Maksima Greka, "Byzantinoslavica” 6, 1935/1936, p. 85-109.

SAlaville S., Liturgies orientales, Paris 1932 [= Bibliothèque catholique des sciences religieuses, 87bis].

ŠEvčEnko I., The Four Worlds and the Two Puzzles of Maxim the Greek, "Palaeoslavica" 19, 2011, p. 294-304. “

ŠevČEnko I., On the Greek Poetic Output of Maksim Grek, "Byzantinoslavica" 58, 1997, p. 1-70.

ŠEvČEnko N.P., The Service of the Virgins's Lament Revisited, [in:] The Cult of the Mother of God in Byzantium. Texts and Images, ed. L. Brubaker, M.B. Cunningham, Farnham 2011 [= Birmingham Byzantine and Ottoman Studies], p. 247-262.

Shoemaker S.J., The Georgian Life of the Virgin attributed to Maximus the Confessor: Its Authenticity(?) and Importance, "Scrinium" 2, 2006, p. 307-328.

Siecienski E.A., The Filioque. A History of a Doctrinal Controvers, New York-Oxford 2010.

Simoniti P., Humanizem na Slovenskem in Slovenski humanisti do srede XVI. stoletja, Ljubljana 1979.

Sinicyna N.V., Archeografičeskij obzor, [in:] Prepodobnyj Maksim Grek, Sočinenija, vol. I, Moskva 2008, p. 511-531.

Sinicyna N.V., Knižnyj master Michail Medovarcev, [in:] Drevnerusskoe iskusstvo. Rukopisnaja kniga, Moskva 1972, p. 286-317.

Sinicyna N.V., Maksim Grek, Moskva 2008 [= Жизнь замечательных людей. Серия биографий / Žizn' zamečatel'nych ljudej. Serija biografij, 1362].

Sinicyna N.V., Maksim Grek v Rossii, Moskva 1977.

Sinicyna N.V., Novye dannye o rossijskom periode žizni prepodobnogo Maksima Greka (materialy dlja naučnoj biografii), "Вестник церковной истории” / "Vestnik cerkovnoj istorii" 4, 2006, p. 221-236.

Sinicyna N.V., Poslanie Maksima Greka Vasiliju III ob ustrojstve afonskich monastyrej (1518-1519 gg.), “Византийский временник” / "Vizantijskij vremennik” 26, 1965, p. 110-136.

Sinicyna N.V., Rannee tvorčestvo prepodobnogo Maksima Greka, [in:] Prepodobnyj Maksim Grek, Sočinenija, vol. I, Moskva 2008, p. 15-83.

Sinicyna N.V., Tvorčestvo prepodobnogo Maksima Greka 30-50 gg. XVI v. i sobranie izbrannych sočinenij iz 47 glav, [in:] Prepodobny Maksim Grek, Sočinenija, vol. II, Moskva 2014, p. 12-47.

Soвolev A.N., Hybrid Grammar in a Macedonian Dialect from Albania, [in:] Indoevropejskoe jazykoznanie i klassičeskaja filologija - XXII (čtenija pamjati I.M. Tronskogo). Materialy Meždunarodnoj konferencii, prochodivšej 18-20 ijunja 2018 g., pars 2, (c. 795-1486), ed. N.N. KaZANSKIJ, Sankt-Peterburg 2018, p. 1243-1255.

Speranzi D., Michele Trivoli e Giano Lascari. Appunti su copisti e manoscritti greci tra Corfù e Firenze, "Studi Slavistici" 7, 2010, p. 263-297.

TAFt R.F., A History of the Liturgy of St. John Chrysostom, vol. V, The Precommunion Rites, Roma 2000 [= Orientalia Christiana Analecta, 261].

Thomson F.J., The Slavonic Translation of the Old Testament, [in:] The Interpretation of the Bible. The International Symposium in Slovenia, ed. J. Krasovec, Sheffield-Ljubljana 1998 [= Journal for the study of the Old Testament. Supplement series, 289], p. 605-920.

Tillyard H.J.W., Byzantine Music and Hymnography, London 1923.

Trubar P., Articuli oli deili te prave stare vere kersanske, Tübingen 1562. 
UsPenskij N.D., Istorija russkogo literaturnogo jazyka (XI-XVII vv.), ${ }^{3}$ Moskva 2002.

UsPenskij N.D., Vizantijskaja liturgija: istoriko-liturgičeskoe issledovanie. Anafora: opyt istoriko-liturgičeskogo analiza, Moskva 2006.

Valiavitcharska V., Rhetoric and Rhythm in Byzantium. The Sound of Persuasion, Cambridge-New York 2013.

Velmans T., Une illustration inédite de l'acathiste et l'iconographie des hymnes liturgiques a Byzance, "Cahiers archéologiques" 22, 1972, p. 132-165.

Verner I.V., Grammatičeskaja sprava Maksima Greka v Psaltyri 1552 g., [in:] Pis'mennost', literatura, fol'klor slavjanskich narodov. Istorija slavistiki, XV Meždunarodnyj s"ezd slavistov, Moskva 2013, p. 104-127.

Verner I.V., K istorii perevoda Psaltiri Maksimom Grekomv 1522-1552 godach: chronologija, tekstologija, metodologija, "Славяноведение" / "Slavjanovedenie" 2, 2017, p. 40-54.

Wellesz E., The "Akathistos". A Study in Byzantine Hymnography, "Dumbarton Oaks Papers" 9/10, 1956, p. 143-174.

Wellesz E., The History of Byzantine Music and Hymnography, ${ }^{2}$ Oxford 1998.

ZajC N., Some Notes on the Life and Works of Maxim the Greek (Michael Trivolis, ca 1470 - Maksim Grek, 1555/1556). Part 1: Biography, "Scrinium" 11, 2015, p. 314-325.

ZaJC N., Some Notes on the Life and Works of Maxim the Greek (Michael Trivolis, ca 1470 - Maksim Grek, 1555/1556). Part 2: Maxim the Greek's Slavic Idiolect, "Scrinium" 12, 2016, p. 375-382.

Žurova L.I., Avtorskij tekst Maksima Greka. Rukopisnaja i literaturnaja tradicii, pars 2, Sočinenija, Novosibirsk 2011.

Abstract. Maximus the Greek has been frequently misunderstood because of his individual use of the Slavic language. Born as Mikhail Trivolis in the Greek town of Arta, he received his humanist education in North Italy, particularly in Florence and Venice, where he was engaged in the process of the first editions of printed books and where he would constantly deal with manuscript samples. His original, authorial work, as preserved in his manuscripts, reflects his awareness of firm Orthodox theology and at the same time a special attention to grammatical rules. The paper shows how his use of the (Slavic) language was at all times intentional and at the same time profoundly influenced by the metrical rules of liturgical emphasis. Through such attitude, Maximus the Greek managed to create his own, deeply personal language and to express the complexity of Byzantine patristic, hagiographic and iconographic issues. Finally, he successfully established his Orthodox theological system, significantly marked with the poetic effect that strongly inspired his theological works.

Keywords: St. Maximus the Greek, the Holy Mount Athos, Manuscripts, Byzantine Hymnography, Orthodox Theology

Neža Zajc

Research Fellow

Institute of Cultural History

Research Centre of Slovenian Academy of Sciences and Arts

Novi trg 2

1000 Ljubljana, Slovenia

nzajc@zrc-sazu.si 